4

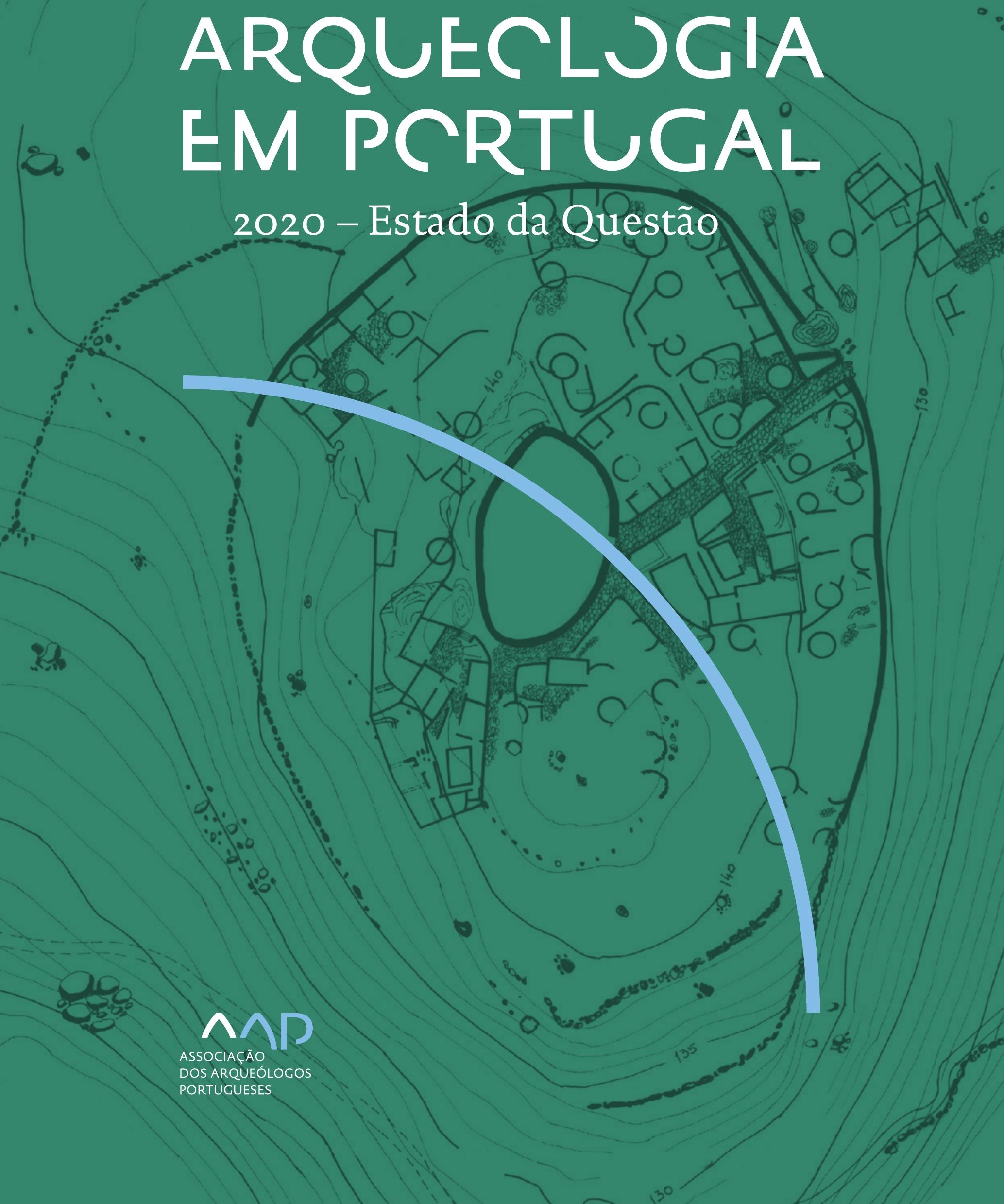


Coordenação editorial: José Morais Arnaud, César Neves e Andrea Martins Design gráfico: Flatland Design

AAP - ISBN: 978-972-9451-89-8

CITCEM - ISBN: 978-989-8970-25-1

Associação dos Arqueólogos Portugueses e CITCEM

Lisboa, 2020

O conteúdo dos artigos é da inteira responsabilidade dos autores. Sendo assim a Associação dos Arqueólogos Portugueses declina qualquer responsabilidade por eventuais equívocos ou questões de ordem ética e legal.

Desenho de capa:

Planta do castro de Monte Mozinho (Museu Municipal de Penafiel).

\section{$\hat{\wedge} \mathrm{P}$}

DOS ARQUEÓLOGOS PORTUGUESES

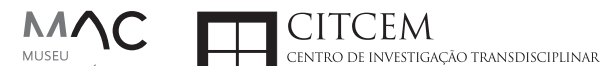
MUSEU
ARQUELLÓGICO
DO CARMO
U.PORTO

FLUP FACULDADE DE LETRAS
UNIVERSIDADE DO PORTO

Apoio

EC para a Ciência 


\section{Índice}

15 Prefácio

José Morais Arnaud

\section{Historiografia e Teoria}

17 Território, comunidade, memória e emoção: a contribuição da história da arqueologia (algumas primeiras e breves reflexões)

Ana Cristina Martins

25 Como descolonizar a arqueologia portuguesa?

Rui Gomes Coelho

41 Arqueologia e Modernidade: uma revisitação pessoal e breve de alguns aspetos da obra homónima de Julian Thomas de 2004

Vítor Oliveira Jorge

57 Dados para a História das Mulheres na Arqueologia portuguesa, dos finais do século XIX aos inícios do século XX: números, nomes e tabelas

Filipa Dimas / Mariana Diniz

73 Retractos da arqueologia portuguesa na imprensa: (in)visibilidades no feminino

Catarina Costeira / Elsa Luís

85 Arqueologia e Arqueólogos no Norte de Portugal Jacinta Bugalhão

101 Vieira Guimarães (1864-1939) e a arqueologia em Tomar: uma abordagem sobre o território e as gentes

João Amendoeira Peixoto / Ana Cristina Martins

115 Os memoráveis? A arqueologia algarvia na imprensa nacional e regional na presente centúria (2001-2019): características, visões do(s) passado(s) e a arqueologia

enquanto marca

Frederico Agosto / João Silva

129 A Evolução da Arqueologia Urbana e a Valorização Patrimonial no Barlavento Algarvio: Os casos de Portimão e Silves

Artur Mateus / Diogo Varandas / Rafael Boavida

\section{Gestão, Valorização e Salvaguarda do Património}

145 O Caderno Reivindicativo e as condições de trabalho em Arqueologia Miguel Rocha / Liliana Matias Carvalho / Regis Barbosa / Mauro Correia / Sara Simões / Jacinta Bugalhão / Sara Brito / Liliana Veríssimo Carvalho / Richard Peace / Pedro Peça / Cézer Santos

155 Os Estudos de Impacte Patrimonial como elemento para uma estratégia sustentável de minimização de impactes no âmbito de reconversões agrícolas Tiago do Pereiro

165 Salvaguarda de Património arqueológico em operações florestais: gestão e sensibilização Filipa Bragança / Gertrudes Zambujo / Sandra Lourenço / Belém Paiva / Carlos Banha / Frederico Tatá Regala / Helena Moura / Jacinta Bugalhão / João Marques / José Correia / Pedro Faria / Samuel Melro

179 Os valores do Património: uma investigação sobre os Sítios Pré-históricos de Arte Rupestre do Vale do Rio Côa e de Siega Verde José Paulo Francisco 
189 Conjugando recursos arqueológicos e naturais para potenciar as visitas ao Geoparque Litoral de Viana do Castelo (Noroeste de Portugal)

Hugo A. Sampaio / Ana M.S. Bettencourt / Susana Marinho / Ricardo Carvalhido

203 Áreas de Potencial Arqueológico na Região do Médio Tejo: Modelo Espacial Preditivo Rita Ferreira Anastácio / Ana Filipa Martins / Luiz Oosterbeek

223 Património Arqueológico e Gestão Territorial: O contributo da Arqueologia para a revisão do PDM de Avis

Ana Cristina Ribeiro

237 A coleção arqueológica do extinto Museu Municipal do Porto - Origens, Percursos e Estudos

Sónia Couto

251 Valpaços - uma nova carta arqueológica

Pedro Pereira / Maria de Fátima Casares Machado

263 Arqueologia na Cidade de Peniche

Adriano Constantino / Luís Rendeiro

273 Arqueologia Urbana: a cidade de Lagos como caso de Estudo Cátia Neto

285 Estratégias de promoção do património cultural subaquático nos Açores. O caso da ilha do Faial

José Luís Neto / José Bettencourt / Luís Borges / Pedro Parreira

297 Carta Arqueológica da Cidade Velha: Uma primeira abordagem

Jaylson Monteiro / Nireide Tavares / Sara da Veiga / Claudino Ramos / Edson Brito /

Carlos Carvalho / Francisco Moreira / Adalberto Tavares

311 Antropologia Virtual: novas metodologias para a análise morfológica e funcional Ricardo Miguel Godinho / Célia Gonçalves

\section{Didáctica da Arqueologia}

327 Como os projetos de Arqueologia podem contribuir para uma comunidade culturalmente mais consciente Alexandra Figueiredo / Claúdio Monteiro / Adolfo Silveira / Ricardo Lopes

337 Educação Patrimonial - Um cidadão esclarecido é um cidadão ativo! Ana Paula Almeida

351 A aproximação da Arqueologia à sala de aula: um caso de estudo no $3^{\circ}$ ciclo do Ensino Básico Luís Serrão Gil

363 Arqueologia 3.o - Pensar e comunicar a Arqueologia para um futuro sustentável Mónica Rolo

377 “Conversa de Arqueólogos" - Divulgar a Arqueologia em tempos de Pandemia Diogo Teixeira Dias

389 Escola Profissional de Arqueologia: desafios e oportunidades Susana Nunes / Dulcineia Pinto / Júlia Silva / Ana Mascarenhas

399 Os Museus de Arqueologia e os Jovens: a oferta educativa para o público adolescente Beatriz Correia Barata / Leonor Medeiros

411 O museu universitário como mediador entre a ciência e a sociedade: o exemplo da secção de arqueologia no Museu de História Natural e da Ciência da Universidade do Porto (MHNC-UP)

Rita Gaspar 
421 Museu de Lanifícios: Real Fábrica de Panos. Atividades no âmbito da Arqueologia Beatriz Correia Barata / Rita Salvado

427 Arqueologia Pública e o caso da localidade da Mata (Torres Novas) Cláudia Manso / Ana Rita Ferreira / Cristiana Ferreira / Vanessa Cardoso Antunes

431 Do sítio arqueológico ao museu: um percurso (também) didático Lídia Fernandes

447 Estão todos convidados para a Festa! E para dançar também... O projecto do Serviço Educativo do Museu Arqueológico do Carmo na $5^{\underline{a}}$ Edição da Festa da Arqueologia Rita Pires dos Santos

459 O “Clã de Carenque”, um projeto didático de arqueologia Eduardo Gonzalez Rocha

469 Mediação cultural: peixe que puxa carroça nas Ruínas Romanas de Troia Inês Vaz Pinto / Ana Patrícia Magalhães / Patrícia Brum / Filipa Santos

481 Didática Arqueológica, experiências do Projeto Mértola Vila Museu Maria de Fátima Palma / Clara Rodrigues / Susana Gómez / Lígia Rafael

\section{Arte Rupestre}

497 Os inventários de arte rupestre em Portugal Mila Simões de Abreu

513 O projeto FIRST-ART - conservação, documentação e gestão das primeiras manifestações de arte rupestre no Sudoeste da Península Ibérica: as grutas do Escoural e Maltravieso Sara Garcês / Hipólito Collado / José Julio García Arranz / Luiz Oosterbeek / António Carlos Silva / Pierluigi Rosina / Hugo Gomes / Anabela Borralheiro Pereira / George Nash / Esmeralda Gomes / Nelson Almeida / Carlos Carpetudo

523 Trabalhos de documentação de arte paleolítica realizados no âmbito do projeto PalæoCôa André Tomás Santos / António Fernando Barbosa / Luís Luís / Marcelo Silvestre / Thierry Aubry

537 Imagens fantasmagóricas, silhuetas elusivas: as figuras humanas na arte do Paleolítico Superior da região do Côa Mário Reis

$55^{1}$ Os motivos zoomórficos representados nas placas de tear de Vila Nova de São Pedro (Azambuja, Portugal) Andrea Martins / César Neves / José M. Arnaud / Mariana Diniz

571 Arte Rupestre do Monte de Góios (Lanhelas, Caminha). Síntese dos resultados dos trabalhos efectuados em 2007-2009 Mário Varela Gomes

599 Gravuras rupestres de barquiformes no Monte de S. Romão, Guimarães, Noroeste de Portugal Daniela Cardoso

613 Círculos segmentados gravados na Bacia do Rio Lima (Noroeste de Portugal): contributos para o seu estudo Diogo Marinho / Ana M.S. Bettencourt / Hugo Aluai Sampaio

631 Equídeos gravados no curso inferior do Rio Mouro, Monção (NW Portugal). Análise preliminar Coutinho, L.M. / Bettencourt, A.M.S / Sampaio, Hugo A.S

645 Paletas na Arte Rupestre do Noroeste de Portugal. Inventário preliminar Bruna Sousa Afonso / Ana M. S. Bettencourt / Hugo A. Sampaio 


\section{Pré-História}

661 O projeto Miño/Minho: balanço de quatro anos de trabalhos arqueológicos Sérgio Monteiro-Rodrigues / João Pedro Cunha-Ribeiro / Eduardo Méndez-Quintas / Carlos Ferreira / Pedro Xavier / José Meireles / Alberto Gomes / Manuel Santonja / Alfredo Pérez-González

677 A ocupação paleolítica da margem esquerda do Baixo Minho: a indústria lítica do sítio de Pedreiras 2 (Monção, Portugal) e a sua integração no contexto regional Carlos Ferreira / João Pedro Cunha-Ribeiro / Sérgio Monteiro-Rodrigues / Eduardo Méndez-Quintas / Pedro Xavier / José Meireles / Alberto Gomes / Manuel Santonja / Alfredo Pérez-González

693 O sítio acheulense do Plistocénico médio da Gruta da Aroeira Joan Daura / Montserrat Sanz / Filipa Rodrigues / Pedro Souto / João Zilhão

703 As sociedades neandertais no Barlavento algarvio: modelos preditivos com recurso aos SIG

Daniela Maio

715 A utilização de quartzo durante o Paleolítico Superior no território dos vales dos rios Vouga e Côa

Cristina Gameiro / Thierry Aubry / Bárbara Costa / Sérgio Gomes / Luís Luís / Carmen Manzano / André Tomás Santos

733 Uma perspetiva diacrónica da ocupação do concheiro do Cabeço da Amoreira (Muge, Portugal) a partir da tecnologia lítica Joana Belmiro / João Cascalheira / Célia Gonçalves

745 Novos dados sobre a Pré-história Antiga no concelho de Palmela. A intervenção arqueológica no sítio do Poceirão I

Michelle Teixeira Santos

757 Problemas em torno de Datas Absolutas Pré-Históricas no Norte do Alentejo Jorge de Oliveira

771 Povoamento pré-histórico nas áreas montanhosas do NO de Portugal: o Abrigo 1 de Vale de Cerdeira Pedro Xavier / José Meireles / Carlos Alves

783 Apreciação do povoamento do Neolítico Inicial na Baixa Bacia do Douro. A Lavra I (Serra da Aboboreira) como caso de estudo Maria de Jesus Sanches

797 O Processo de Neolitização na Plataforma do Mondego: os dados do Sector C do Outeiro dos Castelos de Beijós (Carregal do Sal)

João Carlos de Senna-Martinez / José Manuel Quintã Ventura / Andreia Carvalho / Cíntia Maurício

823 Novos trabalhos na Lapa da Bugalheira (Almonda, Torres Novas) Filipa Rodrigues / Pedro Souto / Artur Ferreira / Alexandre Varanda / Luís Gomes / Helena Gomes / João Zilhão

837 A pedra polida e afeiçoada do sítio do Neolítico médio da Moita do Ourives (Benavente, Portugal)

César Neves

857 Casal do Outeiro (Encarnação, Mafra): novos contributos para o conhecimento do povoamento do Neolítico final na Península de Lisboa.

Cátia Delicado / Carlos Maneira e Costa / Marta Miranda / Ana Catarina Sousa

873 Stresse infantil, morbilidade e mortalidade no sítio arqueológico do Neolítico Final/ Calcolítico ( $4^{\circ}$ e $3^{\circ}$ milénio a.C.) do Monte do Carrascal 2 (Ferreira do Alentejo, Beja) Liliana Matias de Carvalho / Sofia N. Wasterlain 
885 Come together: O Conjunto Megalítico das Motas (Monção, Viana do Castelo) e as expressões Campaniformes do Alto Minho Ana Catarina Basílio / Rui Ramos

899 Trabalhos arqueológicos no sítio Calcolítico da Pedreira do Poio Carla Magalhães / João Muralha / Mário Reis / António Batarda Fernandes

913 O sítio arqueológico de Castanheiro do Vento. Da arquitectura do sítio à arquitectura de um território João Muralha Cardoso

925 Estudo zooarqueológico das faunas do Calcolítico final de Vila Nova de São Pedro (Azambuja, Portugal): Campanhas de 2017 e 2018 Cleia Detry / Ana Catarina Francisco / Mariana Diniz / Andrea Martins / César Neves / José Morais Arnaud

943 As faunas depositadas no Museu Arqueológico do Carmo provenientes de Vila Nova de São Pedro (Azambuja): as campanhas de 1937 a 1967 Ana Catarina Francisco / Cleia Detry / César Neves / Andrea Martins / Mariana Diniz / José Morais Arnaud

959 Análise funcional de material lítico em sílex do castro de Vila Nova de S. Pedro (Azambuja, Portugal): uma primeira abordagem Rafael Lima

971 O recinto da Folha do Ouro 1 (Serpa) no contexto dos recintos de fossos calcolíticos alentejanos

António Carlos Valera / Tiago do Pereiro / Pedro Valério / António M. Monge Soares

\section{Proto-História}

987 Produção de sal marinho na Idade do Bronze do noroeste Português. Alguns dados para uma reflexão

Ana M. S. Bettencourt / Sara Luz / Nuno Oliveira / Pedro P. Simões / Maria Isabel C. Alves / Emílio Abad-Vidal

1001 A estátua-menir do Pedrão ou de São Bartolomeu do Mar (Esposende, noroeste de Portugal) no contexto arqueológico da fachada costeira de entre os rios Neiva e Cávado Ana M. S. Bettencourt / Manuel Santos-Estévez / Pedro Pimenta Simões / Luís Gonçalves

1015 O Castro do Muro (Vandoma/Baltar, Paredes) - notas para uma biografia de ocupação da Idade do Bronze à Idade Média

Maria Antónia D. Silva / Ana M. S. Bettencourt / António Manuel S. P. Silva / Natália Félix

1031 Do Bronze Final à Idade Média - continuidades e hiatos na ocupação de Povoados em Oliveira de Azeméis João Tiago Tavares / Adriaan de Man

1041 As faunas do final da Idade do Bronze no Sul de Portugal: leituras desde o Outeiro do Circo (Beja)

Nelson J. Almeida / Íris Dias / Cleia Detry / Eduardo Porfírio / Miguel Serra

1055 A Espada do Monte das Oliveiras (Serpa) - uma arma do Bronze Pleno do Sudoeste Rui M. G. Monge Soares / Pedro Valério / Mariana Nabais / António M. Monge Soares

1065 São Julião da Branca (Albergaria-a-Velha) - Investigação e valorização de um povoado do Bronze Final

António Manuel S. P. Silva / Paulo A. P. Lemos / Sara Almeida e Silva / Edite Martins de Sá

1083 Do castro de S. João ao Mosteiro de Santa Clara: notícia de uma intervenção arqueológica, em Vila do Conde Rui Pinheiro 
1095 O castro de Ovil (Espinho), um quarto de século de investigação - resultados e questões em aberto

Jorge Fernando Salvador / António Manuel S. P. Silva

1111 O Castro de Salreu (Estarreja), um povoado proto-histórico no litoral do Entre Douro e Vouga

Sara Almeida e Silva / António Manuel S. P. Silva / Paulo A. P. Lemos / Edite Martins de Sá

1127 Castro de Nossa Senhora das Necessidades (Sernancelhe): uma primeira análise artefactual Telma Susana O. Ribeiro

${ }_{1141}$ A cividade de Bagunte. O estado atual da investigação Pedro Brochado de Almeida

1153 Zoomorfos na cerâmica da Idade do Ferro no NW Peninsular: inventário, cronologias e significado Nuno Oliveira / Cristina Seoane

1163 Vasos gregos em Portugal: diferentes maneiras de contar a história do intercâmbio cultural na Idade do Ferro

Daniela Ferreira

1175 Os exotica da necrópole da Idade do Ferro do Olival do Senhor dos Mártires (Alcácer do Sal) no seu contexto regional

Francisco B. Gomes

\section{Antiguidade Clássica e Tardia}

1191 O uso de madeira como combustível no sítio da Quinta de Crestelos (Baixo Sabor): da Idade do Ferro à Romanização Filipe Vaz / João Tereso / Sérgio Simões Pereira / José Sastre / Javier Larrazabal Galarza / Susana Cosme / José António Pereira / Israel Espi

1207 Cultivos de Época Romana no Baixo Sabor: continuidade em tempos de mudança? João Pedro Tereso / Sérgio Simões Pereira / Filipe Santos / Luís Seabra / Filipe Vaz

1221 A casa romana na Hispânia: aplicação dos modelos itálicos nas províncias ibéricas Fernanda Magalhães / Diego Machado / Manuela Martins

1235 As pinturas murais romanas da Rua General Sousa Machado, n. ${ }^{5}$ 1, Chaves José Carvalho

1243 Trás do Castelo (Vale de Mir, Pegarinhos, Alijó) - Uma exploração agrícola romana do Douro

Tony Silvino / Pedro Pereira

1255 A sequência de ocupação no quadrante sudeste de Bracara Augusta: as transformações de uma unidade doméstica Lara Fernandes / Manuela Martins

1263 Os Mosaicos com decoração geométrica e geométrico-vegetalista dos sítios arqueológicos da área do Conuentus Bracaraugustanus. Novas abordagens quanto à conservação, restauro, decoração e datação Maria de Fátima Abraços / Licínia Wrench

1277 “Casa Romana” do Castro de São Domingos (Cristelos, Lousada): Escavação, Estudo e Musealização Paulo André de P. Lemos

1291 A arqueobotânica no Castro de Guifões (Matosinhos, Noroeste de Portugal): O primeiro estudo carpológico

Luís Seabra / Andreia Arezes / Catarina Magalhães / José Varela / João Pedro Tereso 
1305 Um Horreum Augustano na Foz do Douro (Monte do Castelo de Gaia, Vila Nova de Gaia) Rui Ramos

1311 Ponderais romanos na Lusitânia: padrões, formas, materiais e contextos de utilização Diego Barrios Rodríguez

1323 Um almofariz centro-itálico na foz do Mondego

Marco Penajoia

1335 Estruturas romanas de Carnide - Lisboa Luísa Batalha / Mário Monteiro / Guilherme Cardoso

1347 O contexto funerário do sector da "necrópole NO" da Rua das Portas de S. Antão (Lisboa): o espaço, os artefactos, os indivíduos e a sua interconectividade na interpretação do passado Sílvia Loja, José Carlos Quaresma, Nelson Cabaço, Marina Lourenço, Sílvia Casimiro, Rodrigo Banha da Silva, Francisca Alves-Cardoso

${ }_{1361}$ Povoamento em época Romana na Amadora - resultados de um projeto pluridisciplinar Gisela Encarnação / Vanessa Dias

1371 A Arquitectura Residencial em Mirobriga (Santiago do Cacém): contributo a partir de um estudo de caso Filipe Sousa / Catarina Felício

${ }_{1385}$ O fim do ciclo. Saneamento e gestão de resíduos nos edifícios termais de Mirobriga (Santiago do Cacém)

Catarina Felício / Filipe Sousa

1399 Balsa, Topografia e Urbanismo de uma Cidade Portuária Vítor Silva Dias / João Pedro Bernardes / Celso Candeias / Cristina Tété Garcia

1413 No Largo das Mouras Velhas em Faro (2017): novas evidências da necrópole norte de Ossonoba e da sua ocupação medieval Ricardo Costeira da Silva / Paulo Botelho / Fernando Santos / Liliana Nunes

1429 Instrumentos de pesca recuperados numa fábrica de salga em Ossonoba (Faro) Inês Rasteiro / Ricardo Costeira da Silva / Paulo Botelho

1439 A Necrópole Romana do Eirô, Duas Igrejas (Penafiel): intervenção arqueológica de 2016 Laura Sousa / Teresa Soeiro

1457 Ritual, descarte ou afetividade? A presença de Canis lupus familiaris na Necrópole Noroeste de Olisipo (Lisboa)

Beatriz Calapez Santos / Sofia Simões Pereira / Rodrigo Banha da Silva / Sílvia Casimiro / Cleia Detry / Francisca Alves Cardoso

1467 Dinâmicas económicas em Bracara na Antiguidade Tardia Diego Machado / Manuela Martins / Fernanda Magalhães / Natália Botica

1479 Cerâmicas e Vidros da Antiguidade Tardia do Edifício sob a Igreja do Bom Jesus (Vila Nova de Gaia) Joaquim Filipe Ramos

1493 Novos contributos para a topografia histórica de Mértola no período romano e na Antiguidade Tardia Virgílio Lopes

\section{8. Época Medieval}

1511 Cerâmicas islâmicas no Garb setentrional "português": algumas evidências e incógnitas Constança dos Santos / Helena Catarino / Susana Gómez / Maria José Gonçalves / Isabel Inácio / Gonçalo Lopes / Jacinta Bugalhão / Sandra Cavaco / Jaquelina Covaneiro / Isabel Cristina Fernandes / Ana Sofia Gomes 
1525 Contributo para o conhecimento da cosmética islâmica, em Silves, durante a Idade Média Rosa Varela Gomes

1537 Yábura e o seu território - uma análise histórico-arqueológica de Évora entre os séculos VIII-XII José Rui Santos

1547 A encosta sul do Castelo de Palmela - resultados preliminares da escavação arqueológica Luís Filipe Pereira / Michelle Teixeira Santos

1559 A igreja de São Lourenço (Mouraria, Lisboa): um conjunto de silos e de cerâmica medieval islâmica

Andreia Filipa Moreira Rodrigues

1571 O registo material de movimentações populacionais no Médio Tejo, durante os séculos XII-XIII. Dois casos de "sunken featured buildings", nos concelhos de Cartaxo e Torres Novas Marco Liberato / Helena Santos / Nuno Santos

1585 O nordeste transmontano nos alvores da Idade média. Notas para reflexão Ana Maria da Costa Oliveira

1601 Sepulturas escavadas na rocha do Norte de Portugal e do Vale do Douro: primeiros resultados do Projecto SER-NPVD

Mário Jorge Barroca / César Guedes / Andreia Arezes / Ana Maria Oliveira

1619 "Portucalem Castrum Novum" entre o Mediterrâneo e o Atlântico: o estudo dos materiais cerâmicos alto-medievais do arqueossítio da rua de D. Hugo, nํ. 5 (Porto) João Luís Veloso

1627 A Alta Idade Média na fronteira de Lafões: notas preliminares sobre a Arqueologia no Concelho de Vouzela

Manuel Luís Real / Catarina Tente

1641 Um conjunto cerâmico medieval fora de portas: um breve testemunho aveirense Susana Temudo

${ }_{1651}$ Os Lóios do Porto: uma perspetiva integrada no panorama funerário da Baixa Idade Média à Época Moderna em meios urbanos em Portugal

Ana Lema Seabra

1659 O Caminho Português Interior de Santiago como eixo viário na Idade Média Pedro Azevedo

1665 Morfologia Urbana: Um exercício em torno do Castelo de Ourém André Donas-Botto / Jaqueline Pereira

1677 Intervenção arqueológica na Rua Marquês de Pombal/Largo do Espírito Santo (Bucelas, Loures)

Florbela Estêvão / Nathalie Antunes-Ferreira / Dário Ramos Neves / Inês Lisboa

1691 O Cemitério Medieval do Poço do Borratém e a espacialidade funerária na cidade de Lisboa Inês Belém / Vanessa Filipe / Vasco Noronha Vieira / Sónia Ferro / Rodrigo Banha da Silva

1705 Um Espaço Funerário Conventual do séc. XV em Lisboa: o caso do Convento de São Domingos da Cidade Sérgio Pedroso / Sílvia Casimiro / Rodrigo Banha da Silva / Francisca Alves Cardoso

\section{9. Época Moderna e Contemporânea}

1721 Arqueologia Moderna em Portugal: algumas reflexões críticas em torno da quantificação de conjuntos cerâmicos e suas inferências históricas e antropológicas Rodrigo Banha da Silva / André Bargão / Sara da Cruz Ferreira

1733 Faianças de dois contextos entre os finais do século XVI e XVIII do Palácio dos Condes de Penafiel, Lisboa

Martim Lopes / Tomás Mesquita 
1747 Um perfil de consumo do século XVIII na foz do Tejo: O caso do Mercado da Ribeira, Lisboa Sara da Cruz Ferreira / Rodrigo Banha da Silva / André Bargão

1761 Os Cachimbos dos Séculos XVII e XVIII do Palácio Mesquitela e Convento dos Inglesinhos (Lisboa)

Inês Simão / Marina Pinto / João Pimenta / Sara da Cruz Ferreira / André Bargão / Rodrigo Banha da Silva

1775 "Tomar os fumos da erua que chamão em Portugal erua sancta». Estudo de Cachimbos provenientes da Rua do Terreiro do Trigo, Lisboa

Miguel Martins de Sousa / José Pedro Henriques / Vanessa Galiza Filipe

1787 Cachimbos de Barro Caulínitico da Sé da Cidade Velha (República de Cabo Verde)

Rodrigo Banha da Silva / João Pimenta / Clementino Amaro

1801 Algumas considerações sobre espólio não cerâmico recuperado no Largo de Jesus (Lisboa) Carlos Boavida

1815 Adereços de vidro, dos séculos XVI-XVIII, procedentes do antigo Convento de Santana de Lisboa (anéis, braceletes e contas)

Joana Gonçalves / Rosa Varela Gomes / Mário Varela Gomes

1837 Da ostentação, luxo e poder à simplicidade do uso quotidiano: arqueologia e simbologia de joias e adornos da Idade Moderna Portuguesa Jéssica Iglésias

1849 Os amuletos em Portugal - dos objetos às superstições: o coral vermelho Alexandra Vieira

1865 Cerâmicas de Vila Franca de Xira nos séculos XV e XVI Eva Pires

1879 «Não passa por teu o que me pertence». Marcas de individualização associadas a faianças do Convento de Nossa Senhora de Aracoeli, Alcácer do Sal Catarina Parreira / Íris Fragoso / Miguel Martins de Sousa

1891 Cerâmica de Leiria: alguns focos de produção

Jaqueline Pereira / André Donas-Botto

1901 Os Fornos na Rua da Biquinha, em Óbidos Hugo Silva / Filipe Oliveira

1909 A casa de Pêro Fernandes, contador dos contos de D. Manuel I: o sítio arqueológico da Silha do Alferes, Seixal (século XVI) Mariana Nunes Ferreira

1921 O Alto da Vigia (Sintra) e a vigilância e defesa da costa Alexandre Gonçalves / Sandra Santos

1937 O contexto da torre sineira da Igreja de Santa Maria de Loures Paulo Calaveira / Martim Lopes

1949 A Necrópole do Hospital Militar do Castelo de São Jorge e as práticas funerárias na Lisboa de Época Moderna Susana Henriques / Liliana Matias de Carvalho / Ana Amarante / Sofia N. Wasterlain

1963 SAND - Sarilhos Grandes Entre dois Mundos: o adro da Igreja e a Paleobiologia dos ossos humanos recuperados

Paula Alves Pereira / Roger Lee Jesus / Bruno M. Magalhães

1975 Expansão urbana da vila de Cascais no século XVII e XVIII: a intervenção arqueológica na Rua da Vitória no 15 a 17

Tiago Pereira / Vanessa Filipe

1987 Novos dados para o conhecimento do Urbanismo de Faro em época Moderna Ana Rosa 
1995 Um exemplo de Arqueologia Urbana em Alcoutim: o Antigo Edifício dos CTT Marco Fernandes / Marta Dias / Alexandra Gradim / Virgílio Lopes / Susana Gómez Martínez

2007 Palácio dos Ferrazes (Rua das Flores/Rua da Vitória, Porto): a cocheira de Domingos Oliveira Maia

Francisco Raimundo

2021 As muitas vidas de um edifício urbano: História, Arqueologia e Antropologia no antigo Recreatório Paroquial de Penafiel Helena Bernardo / Jorge Sampaio / Marta Borges

2035 O convento de Nossa Senhora da Esperança de Ponta Delgada: o contributo da arqueologia para o conhecimento de um monumento identitário João Gonçalves Araújo / N’Zinga Oliveira

2047 Arqueologia na ilha do Corvo... em busca da capela de Nossa Senhora do Rosário Tânia Manuel Casimiro / José Luís Neto / Luís Borges / Pedro Parreira

2059 Perdidos à vista da Costa. Trabalhos arqueológicos subaquáticos na Barra do Tejo Jorge Freire / José Bettencourt / Augusto Salgado

2071 Arqueologia marítima em Cabo Verde: enquadramento e primeiros resultados do projecto CONCHA

José Bettencourt / Adilson Dias / Carlos Lima / Christelle Chouzenoux / Cristóvão Fonseca / Dúnia Pereira / Gonçalo Lopes / Inês Coelho / Jaylson Monteiro / José Lima / Maria Eugénia Alves / Patrícia Carvalho / Tiago Silva

2085 Trabalhos arqueológicos na Cidade Velha (Ribeira Grande de Santiago, Cabo Verde): reflexões sobre um projecto de investigação e divulgação patrimonial André Teixeira / Jaylson Monteiro / Mariana Mateus / Nireide Tavares / Cristovão Fonseca / Gonçalo C. Lopes / Joana Bento Torres / Dúnia Pereira / André Bargão / Aurélie Mayer / Bruno Zélie / Carlos Lima / Christelle Chouzenoux / Inês Henriques / Inês Pinto Coelho / José Lima / Patrícia Carvalho / Tiago Silva

2103 A antiga fortificação de Quelba / Khor Kalba (E.A.U.). Resultados de quatro campanhas de escavações, problemáticas e perspectivas futuras Rui Carita / Rosa Varela Gomes / Mário Varela Gomes / Kamyar Kamyad

2123 Colónias para homens novos: arqueologia da colonização agrária fascista no noroeste ibérico Xurxo Ayán Vila / José Mạ . Señorán Martín 


\title{
SÃO JULIÃO DA BRANCA \\ (ALBERGARIA-A-VELHA) \\ INVESTIGAÇÃO E VALORIZAÇÃO DE UM POVOADO DO BRONZE FINAL
}

\author{
António Manuel S. P. Silva ${ }^{1}$, Paulo A. P. Lemos ${ }^{2}$, Sara Almeida e Silva ${ }^{3}$, Edite Martins de Sá4
}

\begin{abstract}
RESUMO
O sítio arqueológico de São Julião é um povoado do Bronze Final, situado na plataforma litoral do Entre Douro e Vouga, que tem sido objeto de projetos de investigação sistemática desde 2014. As suas estruturas mais marcantes são a muralha pétrea que delimitava o recinto e um monumento megalítico, violado ou reutilizado em época moderna ou contemporânea. O espólio arqueológico integra um significativo conjunto cerâmico, objetos em pedra e metais, com destaque para um par de brincos em ouro, porventura relacionados com a evidência de metalurgia que se observa no local. Atualmente, está em curso um programa de conservação e valorização da estação arqueológica, com o apoio do Município.

Palavras-chave: Povoado, Idade do Bronze Final, Mamoa, Conservação e valorização, Albergaria-a-Velha.
\end{abstract}

\begin{abstract}
The archaeological site of São Julião is a Late Bronze Age settlement, located on the coastal platform between Douro and Vouga rivers, which has been the subject of systematic research projects since 2014. Its most striking structures are the stone wall that delimited the enclosure and a megalithic mound, violated or reused in modern or contemporary times. The archaeological collection includes a significant set of ceramics, objects in stone and metals, with emphasis on a pair of gold earrings, perhaps related to the evidence of metallurgy that is observed in the place. Currently, a site's archeological conservation and enhancement program is underway, with the support of the Municipality.
\end{abstract}

Keywords: Settlement, Late Bronze Age, Megalithic mound, Archaeological Conservation and enhancement, Albergaria-a-Velha.

\section{O SÍTIO E A SUA INVESTIGAÇÃO}

O povoado de São Julião (Branca, Albergaria-a-Velha) situa-se na primeira cordilheira de relevos significativos que marcam a transição entre as planícies litorais do Baixo Vouga e os contrafortes da
Serra do Arestal. Ocupa uma elevação de configuração ovalada, com cerca de dois hectares de superfície e à cota de 330 metros $^{5}$, com uma excelente visibilidade envolvente, sobretudo sobre a planície atlântica (Figura 1).

Desde há muito referenciado na historiografia re-

\footnotetext{
1. CITCEM - Centro de Investigação Transdisciplinar Cultura, Espaço, Memória (Univ. Porto); Centro de Arqueologia de Arouca. Coordenador do projeto VAL-JUL; amspsilva@hotmail.com.

2. Centro de Arqueologia de Arouca. Investigador do projeto VAL-JUL; paplemos@gmail.com.

3. Centro de Arqueologia de Arouca. Investigadora do projeto VAL-JUL; saralmeidasilva@gmail.com.

4. Centro de Arqueologia de Arouca. Investigadora do projeto VAL-JUL; editesa@gmail.com.

5. 40.770672 lat. N.; -8.470219 long. E.
} 
gional ${ }^{6}$, a natureza e cronologia do sítio só foram estabelecidas na década de 1990, através de uma intervenção arqueológica de emergência realizada na sequência de graves destruições provocadas pela florestação mecânica para o eucaliptal. São Julião foi então caracterizado como um povoado dos finais da Idade do Bronze, delimitado perimetralmente por uma estrutura composta por muro e talude de terra e pedras, propondo-se igualmente, atenta a homogeneidade do espólio cerâmico e a pouca possança dos depósitos arqueológicos, uma ocupação de relativamente curta duração (Silva \& Pereira da Silva, 1995; Silva, 1994; 2005).

Os trabalhos arqueológicos foram retomados em 2014, de forma programada, com o apoio do $\mathrm{Mu}-$ nicípio de Albergaria-a-Velha, ao abrigo de projetos de investigação desenvolvidos pelo Centro de Arqueologia de Arouca, o último dos quais - VAL-JUL $L^{19-21}$ - Estudo, conservação e valorização do sítio arqueológico de São Julião - visando também a valorização arqueológica, patrimonial e ambiental do sítio (Silva \& alii, 2016; 2019b).

Nesta linha, realizaram-se campanhas de escavação anuais, com uma duração de entre três a quatro semanas, envolvendo uma pequena equipa profissional e grupos de voluntários nacionais e estrangeiros, nos anos de 2014, 2015 (Silva $\mathbb{8}$ alii, 2015), 2016, 2017 (Silva \& alii, 2017b e 2019), estando prevista a sua continuidade em 2020. Ao mesmo tempo, têm sido levadas a cabo iniciativas de divulgação da estação arqueológica, quer à escala local (Silva, 2017; Silva \& alii, 2019b), quer promovendo a difusão e o debate junto da comunidade científica sobre aspetos particulares do sítio como as suas muralhas (Silva \& Pereira, 2020), a cerâmica recolhida nas escavações (Almeida e Silva \& alii, 2019) ou a memória oral sobre o arqueossítio (Silva \& alii, 2018-2019). De outros estudos em curso, que envolvem datações radiocarbónicas, análises de paleometalurgia, composição química de pastas cerâmicas, análises arqueobotânicas, prospeção geofísica, etc., aguardam-se desenvolvimentos e oportunidade para a sua discussão e publicação.

Os trabalhos arqueológicos têm incidido, de forma mais continuada, em duas áreas do povoado: a escavação de um troço da estrutura de delimitação do sítio, no talude poente; e a escavação de uma mamoa

6. Para não alongar o texto, vejam-se por exemplo, sobre este aspeto, Silva, 2014; Silva $\&$ alii., 2017b e 2019b. localizada no interior do recinto (Figura 2). Outras sondagens foram feitas na área mais central da parte preservada do sítio (sector $\mathrm{A})^{7}$, em busca de estruturas domésticas, para já sem grande sucesso; e também no prolongamento imediato da plataforma superior para norte (sector C), uma área que tem proporcionado espólio bastante interessante mas que se encontra arruinada, em termos de estratigrafia, devido ao plantio mecânico de eucalipto (Figura 2). Neste texto concentraremos a nossa análise, no que se refere às estruturas arqueológicas, no monumento megalítico e no troço da estrutura de delimitação do sítio.

\section{A MAMOA DE SÃO JULIÃO}

A designada "mamoa 1" de São Julião foi identificada no início da década de 1990, por um de nós (A.M.S.) e Fernando A. Pereira da Silva (1953-2010), no âmbito do reconhecimento da área do povoado proto-histórico. O montículo levantava então algumas dúvidas quanto ao seu contexto funerário, quer pela parca visibilidade da couraça, pela abundante vegetação e acumulação de sedimentos, quer por se encontrar imediatamente contígua a duas grandes crateras de exploração de pedra. Observações posteriores levaram Pereira da Silva a confirmar a identificação do monumento, que considerou de tradição megalítica, descrevendo-o como um tumulus com um diâmetro de pouco mais de 12 metros, coberto por couraça lítica e com dupla violação, propondo, pela morfologia mais ampla das violações, que a mamoa poderia ter encerrado "um dólmen de corredor curto" (Pereira da Silva, 1996, pp. 214-5).

No âmbito dos projetos de investigação que têm enquadrado a segunda fase de trabalhos arqueológicos, surgiu a possibilidade de avaliar e estudar este monumento megalítico, aferir o seu contexto crono-cultural e avaliar as suas características construtivas. A síntese dos resultados dessa pesquisa considera sequencialmente os dados relacionados com o tumulus, ou montículo funerário e, seguidamente, a área central do monumento (Figuras 3 e 4).

\footnotetext{
7. Uma ação de ripagem mecanizada do terreno, em 1992, destruiu por completo cerca de metade da plataforma onde está instalado o povoado, e, desde então, a quase totalidade dos terrenos circundantes, implicando, igualmente, parte da área arqueológica.
} 


\subsection{Tumulus}

As escavações permitiram identificar um tumulus de planta subcircular (ligeiramente ovalado segundo um eixo sudeste-noroeste), com um diâmetro máximo a rondar os $14 \mathrm{~m}$ (Figuras 3 e 4). Destaca-se também a sua pouca altura, que não ultrapassa, em média, os o.50 m, podendo admitir-se talvez um máximo de 0.70 ou $0.80 \mathrm{~m}$ para o topo do monumento, atendendo aos processos erosivos pós-deposicionais e outras ações que terá sofrido ao longo do tempo.

$\mathrm{O}$ monumento encontra-se totalmente revestido por uma couraça pétrea, com exceção das áreas perturbadas pela vegetação e outras ações modernas. A litologia predominante do montículo traduz-se por blocos de média e pequena dimensão de granito local, observando-se, no entanto, uma quantidade apreciável de calhaus de quartzo. Poderá verificar-se, eventualmente, a seleção intencional desta matéria-prima para a sua inserção em determinadas áreas do montículo, e consequente associação entre matérias visualmente contrastantes (Silva et alli, 2017a).

No sector es-nordeste do tumulus, para onde "abre" o incipiente "corredor" da zona da câmara, observa-se uma interrupção da couraça, aparentemente até ao exterior do montículo ${ }^{8}$; mas como a área possui abundantes raízes arbóreas, que perturbaram o subsolo, não é ainda possível interpretar com segurança esta descontinuidade como um "corredor" de acesso ou mera perturbação. Em certos pontos da couraça assinalam-se alguns blocos cuja morfologia e dimensões sugerem que poderiam ter sido esteios constituintes da câmara sepulcral, eventualmente deslocados da sua posição original, mas esta possibilidade requer ainda confirmação (Silva $\mathbb{\&}$ alli, 2018a; Silva \& alli, 2019a).

Os trabalhos mais recentes permitiram detetar um anel lítico periférico, composto por pedras de granito e ocasionais elementos em quartzo, com uma largura de cerca de dois metros. A sua implantação foi precedida pela colocação de um depósito de preparação e nivelamento, diretamente sobre a rocha de base, eventualmente nos locais onde a mesma não foi afeiçoada ou regularizada para o efeito, conferindo desta forma uma maior sustentabilidade estru-

8. Curiosamente, também F. A. Pereira da Silva - talvez induzido pela maior destruição ou abaixamento da couraça nessa parte do tumulus - sugeria que o pequeno corredor da sepultura megalítica poderia abrir para um "átrio" (1996, p. 214). tural a este elemento arquitetónico. Apesar de não ser possível apurar na íntegra, por ora, o processo de preparação do solo levado a cabo para receber a estrutura, os dados de que dispomos atestam um cuidado planeamento e faseamento construtivo, bem como a sua adaptação e articulação com as características morfológicas do terreno (Silva \& alli, 2019a).

\section{2. Área central do monumento}

A intervenção na área central da estrutura, onde se localizaria uma eventual câmara sepulcral, revelou surpresas e consideráveis desafios interpretativos, resultantes de grandes perturbações ocorridas em época moderna/contemporânea.

Após os trabalhos superficiais de limpeza e da decapagem de um nível de saibro granítico de aparente aspeto natural, observou-se uma vala preenchida por uma espécie de "anel lítico", composto por blocos de pedra de maiores dimensões que a pareciam delimitar. Ainda foi colocada a hipótese desse anel lítico, rebaixando um pouco a cota basal do monumento, ter tido funções de contrafortagem de uma câmara sepulcral megalítica ou submegalítica, entretanto desmantelada e removida, ou simplesmente de delimitação simbólica do espaço. Porém, sob estas estruturas, colmatadas (quase diríamos, pela aparência, "condenadas", na aceção simbólica que se dá a este termo nestes contextos pré-históricos) por inúmeros blocos de pedra de pequena e média dimensão, observou-se uma segunda fossa, também escavada no nível geológico natural, de configuração subquadrangular, com ângulos arredondados, medindo regularmente 1.80 x $1.80 \mathrm{~m}$ e com orientação OSO-ENE, a considerar-se este parâmetro (Figura 5).

A escavação desta fossa inferior, cujo topo estava também colmatado por blocos de pedra de pequena e média dimensão (aparentemente da litologia local, sem seleção evidente) viria a revelar que a fossa se encontrava seccionada transversalmente, sensivelmente pela metade, no sentido aproximado sudeste-noroeste, por um murete de três fiadas de pedras, sobrepostas sem qualquer ligante e que não atingiam o fundo da fossa, assentando ainda sobre sedimentos (Figura 5). Na sua metade es-nordeste, a fossa estava superiormente capeada por um pavimento em saibro pisado, relativamente compacto; a "metade" oposta da estrutura negativa achava-se preenchida por cinco depósitos de terra e pedras. Importa recordar, como se disse, que o "murete" septal não atin- 
gia a base da fossa, apoiando-se em três depósitos sedimentares linearmente sucedâneos (Silva $\mathbb{Z}$ alli, 2018a; Silva \& alli, 2019a).

A escavação destes depósitos, incluindo a desmontagem parcial do murete intermédio, forneceu escasso espólio arqueológico e, surpreendentemente, praticamente todo de cronologia moderna ou contemporânea, essencialmente fragmentos de material de construção (telha). Os níveis [113] a [115], subjacentes ao piso em saibro (UE o9o) não revelaram conteúdo artefactual; o murete [89] apenas um fragmento de telha e os seis depósitos subjacentes ao murete proporcionaram a recolha de 32 fragmentos de cerâmica moderna/contemporânea. Apenas foi registado um pequeno fragmento de cerâmica proto-histórica (afim da do povoado), no nível basal [125], mas coexistindo com seis fragmentos modernos; e no depósito [88] recolheu-se um geométrico em sílex, que todavia estava "acompanhado" por 14 fragmentos de telha e outra louça moderna (Silva \& alii, 2017a; 2018a; 2019b).

Ou seja, a avaliar pelo espólio recolhido nesta estranha fossa, temos de admitir duas interpretações possíveis: ou a fossa - e as ações construtivas correlatas - é de cronologia moderna/contemporânea (precisemos, entre os séculos XVIII e XX) e no mesmo intervalo cronológico foi abandonada e/ou colmatada; ou a fossa é de cronologia pré ou proto-histórica e foi, em tempos modernos, reutilizada - incluindo a construção do murete septal e o respetivo "meio-piso" superior - e posteriormente abandonada e atulhada com depósitos de aterro modernos/contemporâneos.

$\mathrm{Na}$ verdade, esta estranha súmula de ações antrópicas dificulta uma cabal interpretação dos dados, pelo que apenas nos é permitido, por ora, sustentar algumas hipóteses interpretativas para a compreensão deste ambiente e dos seus diferentes momentos construtivos, de eventual reformulação e, certamente, de violação/destruição/reutilização (?). Equaciona-se, assim, a possibilidade de ter sido ali erigida uma câmara submegalítica ou cistóide (atendendo à tipologia das lajes aparentemente deslocadas e presentes no montículo), ou alongada e sem corredor, ou com um corredor muito incipiente, o que em conjunto com as restantes características arquitetónicas do tumulus poderia corresponder a um monumento inserível cronologicamente no $3^{\circ}$ milénio ou no início do $2^{\circ}$ milénio (Calcolítico/Bronze Inicial) (Silva \& alli, 2018a; 2019a).
Ainda que esteja em aberto a hipótese da fossa subquadrangular ter integrado o conjunto sepulcral original, possibilidade que conta com alguns paralelos regionais (Jorge, 1985; Pereira da Silva, 1992; Carvalho, 2016), ou que a mesma estrutura possa, em alternativa ter resultado de uma reapropriação/reutilização coeva da ocupação do povoado no Bronze Final, não restam dúvidas - como atrás se explica - de que as ações patentes no seu enchimento evidenciam a sua violação/destruição/reutilização, ocorrida provavelmente entre os séculos XIX e XX, fosse no âmbito das explorações das pedreiras próximas ou da utilização do posto de telegrafia ótica que ali existiu9. Temos também de admitir, como terceira possibilidade, que a própria fossa subquadrangular seja de época histórica e que possa ter tido uma funcionalidade, que de todo nos escapa por enquanto, porventura associada a estes últimos eventos. Se assim foi, tal ação pode ter implicado o saque total dos esteios da presumível câmara ou cista e/ ou de uma eventual fossa/covacho associados, de menores dimensões, o que é já especulativo (Silva $\&$ alli, 2019a).

O espólio proveniente do monumento, considerando também a área do tumulus, acentua as dificuldades interpretativas, pois os materiais exumados são, na sua grande maioria, de cronologia moderna/contemporânea. A sua prevalência verifica-se quer nas áreas genéricas da mamoa, quer nos depósitos de enchimento da fossa central, como vimos. A escassez de espólio coevo do monumento ou mesmo da ocupação do povoado constitui, talvez, a problemática mais desafiadora, atendendo à sua percentagem diminuta e à evidência de grandes perturbações da estratigrafia original. A par das parcas cerâmicas que deverão integrar-se nos mesmos horizontes da ocupação do final da Idade do Bronze, destaca-se a ocorrência de algumas lâminas e lamelas em sílex, um bloco de quartzo com levantamentos e um geométrico (Silva \& alli, 2019a). Admite-se, com as devidas reservas, decorrentes dos factores referidos, que os artefactos em pedra talhada poderão ser os

\footnotetext{
9. De onde resulta o microtopónimo "Talégre» usado pela população local para referenciar o monte. O posto do "Alto da Branca" terá sido instalado no contexto da guerra civil liberal, e deverá ter funcionado pelo menos até meados do século XIX. Desconhece-se qual o sistema utilizado (telégrafo de persianas, de ponteiro ou outro) e que tipo de construção ou dispositivos de apoio implicou.
} 
únicos elementos artefactuais eventualmente integrantes no espólio votivo e na ambiência crono-cultural desta estrutura funerária pré-histórica - ou, pelo menos, da fruição mais remota da sua biografia (Figura 6).

\section{A ESTRUTURA DE DELIMITAÇÃO DO POVOADO}

A presença de muralhas em São Julião encontra-se registada desde, pelo menos, as Memórias Paroquiais de 1758 (Azevedo, 1896, p. 313), acompanhando também as primeiras interpretações de pendor arqueológico do sítio (Gomes, 1877, p. 69; Souto, 1942, p. 31; Almeida, 1946, p. 42) com textos descritivos e, por vezes, imagens, que evidenciavam que tal estrutura mostrava à época ainda alguma imponência (Silva et al. 2017b, p. 25). Reconhecida também nos trabalhos de 1993-1994 (Pereira da Silva \& Silva, 1993; 1994; Silva \& Pereira da Silva, 1995), a estrutura de delimitação do povoado, identificada em especial na encosta oeste, foi, durante os trabalhos dos projetos de investigação PROBA e PROBA ${ }^{+2}$, e, agora, VAL-JUL, alvo de novas intervenções.

Em 2014 procedeu-se à limpeza da área sondada nos trabalhos dos anos '9o e à abertura de uma nova sondagem, com o objetivo de caracterizar melhor a estrutura murária. Os trabalhos demonstraram a perturbação dos depósitos subjacentes à estrutura de delimitação, na sequência de ações de plantio recentes, verificando-se ainda que a mesma tinha sido reformulada em época moderna/contemporânea. Contudo, foi possível identificar dois depósitos relacionados com a construção da estrutura, tendo, de um desses depósitos, sido recolhida uma amostra de sedimentos que possibilitou a datação de um carvão de medronheiro. A data obtida (976-826 a.C.) aponta um terminus post quem para a edificação desta estrutura (Quadro 1). Em 2015, os trabalhos realizados permitiram a identificação, a Este, de um possível muro, bastante desmantelado, constituído por blocos de granito de médio calibre, relativamente aparelhados, sem qualquer ligante, ostentando cerca de dois metros de largura, com enchimento de terra e pedras de diferentes calibres. Entre 2016 e 2019 procedeu-se a diversos alargamentos da superfície escavada, afinando-se a compreensão do processo construtivo da estrutura de delimitação, exumada já numa extensão de $24 \mathrm{~m}$, numa superfície total de $176 \mathrm{~m}^{2}$.
Dos trabalhos realizados podemos afirmar que o povoado era dotado, aparentemente desde a sua origem, de uma estrutura de delimitação que, muito possivelmente, rodeava toda a plataforma superior do cabeço de São Julião, tal como sugerido pela bibliografia mais antiga. Infelizmente, em resultado da florestação e outras ações humanas, apenas é visível, atualmente, na encosta poente da plataforma. Podemos caracterizar a estrutura de delimitação como sendo composta por duas partes complementares. A primeira, um muro composto por pedra seca, integrando essencialmente blocos de granito de pequenas a grandes dimensões, com face externa relativamente alinhada e espessura de 3,5 m. A "face interna" deste muro pétreo não é muito evidente, embora se note uma concentração de blocos de maior dimensão, que poderão ter funcionado como "fecho" da estrutura (Figuras. 6 e 7). Não temos elementos para estimar o seu alçado original, que temos reconstituído graficamente com uma altura a rondar os dois metros (Silva \& alii, 2016; 2016b; Silva $\&$ Pereira, 2020). A segunda, por sua vez, refere-se a uma estrutura interna, caracterizada por um talude constituído por terras e pedras em declive, adossado ao muro anterior, servindo quer de contraforte, quer de rampa de acesso ao topo do muro externo. A circunstância dos depósitos inferiores deste talude assentarem parcialmente sobre a estrutura basal do muro exterior sugere que ambos os elementos de delimitação, muro e talude, tenham feito parte do mesmo projeto construtivo, de que parece ter resultado, em síntese, uma espessa linha de delimitação, com cerca de quatro ou cinco metros de espessura total. O que, entretanto, podemos sublinhar é o grande interesse desta estrutura de contenção, como exemplo da diversidade dos dispositivos e arquiteturas que delimitavam os povoados desta época na região, considerando, por exemplo, os casos próximos dos sítios da Cividade ou do Senhor dos Aflitos, em Arouca (Silva \& Leite, 2010; Silva \& alii, 2018b; Silva \& Lemos, 2018; Silva \& Pereira, 2020), mas também os de outros povoados com menos documentação, situação que, aliás, se regista também à escala do norte do país (Bettencourt \& Sanches 1998; Bettencourt, 2000; Vieira, 2014).

\section{ESPÓLIO ARQUEOLÓGICO}

Ascendem já a cerca de 22 ooo objetos as recolhas de materiais resultantes das campanhas de 2014 a 
2019, sendo naturalmente mais volumoso o espólio cerâmico, que acusa uma assinalável homogeneidade, resultante talvez da relativamente curta diacronia de ocupação do sítio. Entre os outros itens destacam-se os artefactos líticos, em pedra talhada e polida e alguns objetos metálicos, com realce para um par de brincos áureos (Figura 8).

No que respeita à olaria (Almeida e Silva $\&$ alli, 2018-19; SILVA $\&$ alli, 2015, pp. 84-5; Silva $\&$ alli, 2017b, pp. 32-4), apesar do elevado grau de fragmentação do espólio, tem vindo a ser possível reconhecer algumas tipologias formais (Almeida e Silva $\mathbb{E}$ alli, 2018-19, pp. 28-31), sobretudo em virtude dos trabalhos realizados na zona C (Figura 2), onde a concentração de cerâmica proto-histórica é bastante superior, comparativamente a outras áreas do povoado. São sobretudo potes e potinhos, com diferentes tipos de bordo, aos quais se somam algumas taças carenadas (Figura 8-2), também de diferentes tipologias, e alguns recipientes de maiores dimensões destinados ao armazenamento, identificando-se também a presença de uma queijeira ou coador. O número residual de asas recolhido indica que não seriam muito abundantes as formas com elas (Figura $8-1$ ). Fora do reportório de uso alimentar está um conjunto de elementos relacionados com a metalurgia do bronze ${ }^{10}$, no qual se inserem cadinhos e moldes de fundição (Figura 8 - 5 a 7 ), o que sublinha a importância regional deste sítio do Bronze Final, bem como um cossoiro e um peso, talvez de rede.

A cerâmica de São Julião apresenta maioritariamente produção manual, cozedura mediana ou má, pastas arenosas ou areno-micáceas, sendo as primeiras pouco depuradas. As superfícies não apresentam tratamento cuidado, salvo raras exceções, não sendo também frequente a decoração (Almeida e Silva $\mathbb{8}$ alli, 2018-19, pp. 14-25), que surge maioritariamente sobre os lábios ou já na superfície interna, através de incisões ou impressão de dedadas (Figura 8-1 e 4), e sobre as panças, aí sob a forma maioritária de caneluras (Figura 8-14). Se em alguns casos parece evidente a intenção ornamental, outros há em que

10. Chegamos a considerar estes elementos, caracterizados por pastas de tonalidade bege-acinzentada, bastante depuradas, como possíveis peças de importação (Almeida e Silva et alli, 2018-19, p. 14). Apenas com o desenrolar dos trabalhos, e o surgimento de mais elementos, foi possível perceber que se tratava de moldes para fundição, não tendo sido ainda possível apurar a proveniência da argila utilizada na sua produção. ligeiras caneluras ou linhas incisas poderão resultar apenas do tratamento de superfície, por vezes aparentemente feito com escova. As linhas incisas são comuns, dispondo-se por vezes em aspa ou zig-zague e, mais raramente, em padrão geométrico ( $\mathrm{Fi}$ gura 8 - 10, 12). Verifica-se a existência de um fragmento com incisão pós-cozedura (Figura 8-11), e de outros decorados com pequenos puncionamentos $\mathrm{e}$ outros motivos impressos (dedadas, círculos, motivos subtriangulares, etc.) (Figura $8-13$ ). O brunido é bastante raro como acabamento, estando representado apenas por um exemplar, de alta qualidade (Figura 8-9).

São pouco mais de uma centena os objetos em pedra recolhidos no povoado (SILVA \& alli, 2015, p. 85; SILVA \& alli, 2017b, p. 34). Entre os elementos polidos surgem os relacionados com a moagem (dormentes e moventes de mós manuais), alguns amoladores, uma goiva, um machado e um conjunto significativo de pesos de rede, obtidos através de duplo entalhe paralelo sobre seixo de rio. Já entre os objetos produzidos através de talhe (Figura 9-1 a 10), sob quartzo ou sílex, destacam-se as lâminas (Figura $9-6$ a 8), algumas lamelas e lascas (Figura 9 - 1 a 5) e dois geométricos (Figura 9 - 9 e 10), ambos recolhidos na zona da mamoa.

Relativamente aos metais (SILVA \& alli, 2017b, p. 34) verifica-se a presença de seis objetos enquadráveis no Bronze Final ${ }^{11}$, sendo quatro em bronze e dois em ouro (Figura 9). Dois dos objetos em bronze são de dimensões diminutas, não sendo possível apurar a sua funcionalidade (Figura 9 - 13 e 14); um outro corresponde a um aro de uma possível bracelete ou objeto de adorno (Figura 9-12), e o restante a uma lâmina (Figura 9-11). Quanto às peças em ouro (Figura 9 - 15 e 16), um par de brincos, apresentam-se muito similares entre si, tendo sido produzidos através de fio de ouro maciço, dobrado em argola aberta, com secção ovalada e superfícies levemente facetadas, medindo cerca de $15 \mathrm{~mm}$ e pesando $6 \mathrm{~g}$. cada. Não é esta a ocasião discutir contextos, significados ou cronologias destas peças áureas, usualmente classificadas da $1^{\mathrm{a}}$ Idade do Ferro, ou seja, globalmente entre os séculos VIII-VII e V a.C., mas deverá anotar-se que são conhecidas apenas oito objetos similares em todo o País, todos provenientes da Estremadura: dois brincos da Boiça do Louro, Cadaval, outros

11. Havia sido recolhido, também, um ceitil de D. Afonso V (1438-1481). 
dois da Boiça, Alcobaça e finalmente quatro do Casal das Passadeiras, Torres Vedras, sendo que apenas o último achado tem contexto arqueológico, uma vez que apareceu em conjunto com outras peças áureas (Silva, A. R., 2014).

\section{A VALORIZAÇÃO DO SÍTIO ARQUEOLÓGICO}

O projeto de conservação e valorização, iniciado em 2020, em colaboração com o Município local, que tem financiado integralmente os trabalhos e procedeu à aquisição dos terrenos melhor conservados da estação arqueológica, visa assegurar a conservação e acessibilidade dos vestígios arqueológicos e a valorização das memórias da antropização do sítio em vários planos cronológicos, desde a pré-história (mamoa), passando pela Idade do Bronze até aos tempos modernos, marcados pela exploração artesanal de pedreiras ou pela instalação de um posto de telegrafia ótica no segundo quartel do século XIX, episódio que perpetuou a designação microtoponímica de "Alto do Talégre» aplicada ao local.

Em colaboração com uma associação da região, a BioLiving, pretende-se também intervir para a requalificação ambiental do sítio, que inclui a desflorestação das espécies exógenas de crescimento rápido e a promoção do coberto florestal e arbustivo autóctone. Desta forma, o programa de investigação arqueológica complementar-se-á com a «devolução" à comunidade, com valor acrescido, dos conhecimentos obtidos, preservando e requalificando o património cultural e potenciando novas áreas de saber e lazer (Silva \& alii, 2019b).

\section{NOTA FINAL}

Para além dos valores patrimoniais que, desde cedo, se anteviu que poderiam acrescer significado ao sítio no plano regional, a estação arqueológica de São Julião tem vindo a suscitar importantes questões no plano do conhecimento da proto-história do Centro e Norte de Portugal. Para tal concorrem, como elementos maiores, a sua muralha (ou de forma menos bélica, como preferimos dizer, "estrutura de delimitação"), que é já um referencial de investigação à escala regional; e a estranhíssima mamoa "acolhida" dentro do povoado. Estranha pela sua localização incomum, pelos diálogos de ritual e simbólica que certamente "entabulou" com os antigos residentes; estranha sobretudo pela insólita reutilização da sua área central, primordialmente sepulcral, se bem que disso não reste qualquer vestígio arquitetónico.

Mas não deixa, igualmente, de suscitar ricas questões ao historiador dos tempos sem escrita a natureza do "povoado" e dos seus lares e dispositivos do quotidiano. Da aldeia de cabanas singelas em que durante alguns séculos se multiplicaram famílias e alimentaram gerações, a invisibilidade estrutural é quase absoluta. Apenas por indícios indiretos se chega ao quotidiano e às gentes que habitaram aqueles altos: os restos de barro mal cozido que calafetavam as ramagens das cabanas ou pavimentavam o chão onde a família se aquecia à lareira, as mós onde grosseiramente se triturava o ralo pão, os utensílios de pedra lascada ou polida, reutilizados dos antepassados para novos usos e funções, um raro cossoiro a atestar a fiação de alguma fibra animal ou vegetal. Mas o "novo" e o excecional também ali tinham lugar-e porventura com uma expressão que ainda nem conseguimos antever: acumulam-se os objetos que testemunham a prática metalúrgica em São Julião, e o par de brincos áureos recorda-nos os signos de poder e hierarquia que o próprio trabalho dos metais já anuncia.

Enquanto se aguardam os resultados de novas datações por Carbono 14, interessa destacar a extraordinária homogeneidade daquelas já disponíveis (Quadro 1), uma relacionada com a construção da muralha (Sondagem 2), a segunda numa área bastante perturbada mas de onde procedem relevantes itens de espólio, ambas apontando para um horizonte de ocupação em pleno "Bronze Final Atlântico”, entre os séculos X e IX a.C.

\section{BIBLIOGRAFIA}

ALMEIDA, João de (1946) - Roteiro dos monumentos militares portugueses. II. Lisboa: Ed. A., pp. 40-2.

ALMEIDA E SILVA, Sara; SILVA, António Manuel S. P.; LEMOS, Paulo A. P.; PEREIRA, Gabriel R. (2018-2019) - Cerâmica proto-histórica do povoado de São Julião (Albergaria-a-Velha): estudo preliminar. Oppidum - Revista de Arqueologia, História e Património, 11, Lousada, pp. 9-36.

AZEVEDO, Pedro A. (1896) - Extractos archeologicos das Memórias Parochiais de 1758. O Archeólogo Portuguez. 2. Lisboa, pp. 305-18.

BETTENCOURT, Ana M. S. (200o) - Estações da Idade do Bronze e inícios da Idade do Ferro da Bacia do Cávado (Norte de Portugal). Braga: Universidade do Minho.

BETTENCOURT, Ana M. S.; SANCHES, Maria J. (1998) Algumas questões sobre a Idade do Bronze do Norte de Por- 
tugal. In FÁBREGAS, R. (ed.) - A Idade do Bronce en Galicia: novas perspectivas. A Coruña: Edicios do Castro: 13-45.

CARVALHO, Pedro M. S. (2016) - Taco a Taco: a história de dois monumentos. Albergaria-a-Velha: Câmara Municipal.

GOMES, João Marques (1877) - O Districto de Aveiro: Noticia geographica, estatistica, chorographica, heraldica, archeologica ... Coimbra: Imprensa da Universidade.

JORGE, Vítor O. (1985) - Les tumulus de Chã de Santinhos (ensemble mégalithique de Serra da Aboboreira, Nord du Portugal). Arqueologia, 12. Porto, pp. 96-128.

PEREIRA DA SILVA, Fernando A. (1992) - A Necrópole Megalítica do Taco (Albergaria-a-Velha). Trabalhos de Antropologia e Etnologia. 32, Porto, pp. 263-292

PEREIRA DA SILVA, Fernando A.; SILVA, António Manuel S. P. (1993) - Estação arqueológica de S. Julião (. . .). Relatório da $1^{\underline{a}}$. Campanha de Escavações (abril de 1993). Oliveira de Azeméis. Texto dactilografado

PEREIRA DA SILVA, Fernando A.; SILVA, António Manuel S. P. (1994) - Estação arqueológica de S.Julião (...). Relatório da $2^{\underline{a}}$. Campanha de Escavações. Oliveira de Azeméis. Texto datilografado.

PEREIRA DA SILVA, Fernando A. (1996) - Megalitismo a Sul do Douro: Bacias do Vouga e Alto Paiva. Práticas funerárias no Centro-Norte Litoral de Portugal durante a Pré-história Recente. 1.2 - Tumuli do Centro-Norte Litoral: Inventário. Tese de Doutoramento inédita, em preparação para apresentação na Universidade do Porto.

SILVA, Ana R. Vaz (2014) - Leituras sobre Ourivesaria Arcaica Portuguesa. Brincos, Contextos e Expressão Territorial. Coimbra. Dissertação de Mestrado em Arqueologia e Território apresentada à Faculdade de Letras da Universidade de Coimbra.

SILVA, António Manuel S. P. (1994) - Proto-história e Romanização no Entre Douro e Vouga Litoral. Elementos para uma avaliação crítica. Dissertação de Mestrado apresentada à Faculdade de Letras da Universidade do Porto.

SILVA, António Manuel S. P. (2005) - Povoamento proto-histórico no Entre Douro e Vouga Litoral: a estruturação do habitat. I - Arquitectura dos castros. In Castro, um lugar para habitar. Colóquio [Cadernos do Museu, 11]. Penafiel: Museu Municipal, pp. 167-188.

SILVA, António Manuel S. P (2014) - Dos vestígios do passado ao património arqueológico. Algumas reflexões sobre a Arqueologia de Albergaria-a-Velha. Albergue. História e Património do Concelho de Albergaria-a-Velha. 1. Albergaria-a-Velha, pp. 27-6o.

SILVA, António Manuel S. P. (2017) - O povoado proto-histórico de São Julião da Branca. In FERREIRA, Delfim B. (coord.) - 90o Anos. Albergaria-a-Velha. 1117-2017. Das origens a Osseloa. Exposição. Albergaria-a-Velha: Câmara Municipal, pp. 8-14 (não pag.).
SILVA, António Manuel S. P.; LEITE, Joana N. (2010) - The place of Cividade. An approach to Late Bronze/Iron Age transition in Arouca valley (NW Portugal). In BETTENCOURT, A. ; SANCHES, M.; ALVES, L.; FABREGAS VALCARCE, R. (eds.) - Conceptualizing space and place. On the role of agency, memory and identity in the construction of space from the Upper Paleolithic to the Iron Age in Europe. (Proc. of the $15^{\text {th }}$ Crongress of UISPP). Oxford: Archaeopress, pp. 153-6o.

SILVA, António Manuel S. P.; LEMOS, Paulo A. P. (2018) - Sondagem arqueológica no povoado da Idade do Bronze do Senhor dos Aflitos (Arouca, Centro-Norte de Portugal). In HERNÁNDEZ GUTIÉRREZ, N.; LARRAZABAL GALARZA, J.; PORTERO HERNÁNDEZ, R. (coord.) - Arqueologia en el valle del Duero: del Paleolítico a la Edad Media 6 - Actas de las VI Jornadas de Arqueología del valle del Duero. Valladolid: Glyphos, p. 191-203

SILVA, António Manuel S. P.; PEREIRA, Gabriel R. (2020) - Walls and Castros. Delimitation structures in the Protohistoric settlements of Entre Douro and Vouga region (Center-North of Portugal). In DELFINO, D.; COIMBRA, F. CARDOSO, D.; CRUZ, G. - Late Prehistoric Fortifications in Europe: Defensive, symbolic and territorial aspects from the Chalcolithic to the Iron Age. Oxford: Archaeopress, pp. 215-228.

SILVA, António Manuel S. P.; PEREIRA DA SILVA, Fernando A. (1995) - O Povoado de S. Julião (Branca, Albergaria-a-Velha, Aveiro). In SILVA, Isabel (coord.), A Idade do Bronze em Portugal. Discursos de poder. Lisboa: Instituto Português de Museus, p. 123.

SILVA, António Manuel S. P.; PEREIRA, Gabriel R.; LEMOS, Paulo A. P.; ALMEIDA e SILVA, Sara (2015) - Escavações arqueológicas em São Julião da Branca (Albergaria-a-Velha). Campanhas de 2014-2015. Albergue. História e Património do Concelho de Albergaria-a-Velha. 2. Albergaria-a-Velha, pp. 59-91.

SILVA, António Manuel S. P.; PEREIRA, Gabriel R.; TAVARES, João T.; LEMOS, Paulo A. P.; ALMEIDA E SILVA, Sara (2016) - Proto-história da Bacia do Antuã (2011-2015) - um projeto de investigação arqueológica em rede. Patrimónios de OAZ. № o. Oliveira de Azeméis: Câmara Municipal, pp. 77-96.

SILVA, António Manuel S. P.; PEREIRA, Gabriel R.; LEMOS, Paulo A. P.; ALMEIDA E SILVA, Sara (2017a) - Proto-história da Bacia do Antuã [Projeto de Investigação Arqueológica 2016-2017]. Povoado de São Julião | Albergaria-a-Velha. Aveiro. Relatório da 4 ${ }^{a}$ Campanha de Trabalhos Arqueológicos. Texto policopiado.

SILVA, António Manuel S. P.; PEREIRA, Gabriel R.; LEMOS, Paulo A. P.; ALMEIDA E SILVA, Sara (2017b) - São Julião da Branca e o povoamento do Entre Douro e Vouga na transição entre a Idade do Bronze e a Idade do Ferro. Albergue. História e Património do Concelho de Albergaria-a-Velha. 4. Albergaria-a-Velha, pp. 15-40. 
SILVA, António Manuel S. P.; PEREIRA, Gabriel R.; LEMOS, Paulo A. P.; ALMEIDA E SILVA, Sara (2018a) - Proto-história da bacia do Antuã (...). Povoado de São Julião, Albergaria-a-Velha, Aveiro. Relatório da 4 ${ }^{\underline{a}}$. campanha de trabalhos arqueológicos. Arouca: Centro de Arqueologia de Arouca. Texto policopiado.

SILVA, António Manuel S. P.; PEREIRA, Gabriel R.; LEMOS, Paulo A. P.; ALMEIDA E SILVA, Sara (2018b) - A Idade do Bronze na margem sul do Baixo Douro - sítios e pistas de investigação. In HERNÁNDEZ GUTIÉRREZ, N.; LARRAZABAL GALARZA, J.; PORTERO HERNÁNDEZ, R. (coord.) - Arqueologia en el valle del Duero: del Paleolítico a la Edad Media 6 - Actas de las VI Jornadas de Arqueología del valle del Duero. Valladolid: Glyphos, pp. 92-117.

SILVA, António Manuel S. P.; PEREIRA, Gabriel R.; LEMOS, Paulo A. P.; ALMEIDA E SILVA, Sara (2019a) - Proto-história da Bacia do Antuã. [Projeto de Investigação Arqueológica 2016-2018]. Povoado de São Julião| Albergaria-a-Velha. Aveiro. Relatório da $5^{\mathrm{a}}$ Campanha de Trabalhos Arqueológicos. Texto policopiado.
SILVA, António Manuel S. P.; SÁ, Edite M.; LEMOS, Paulo; ALMEIDA E SILVA, Sara (2019b) - Projeto de valorização do sítio do Alto do Talégre/São Julião (Branca, Albergaria-a-Velha). Investigar o Passado e (re)construir memórias. Albergue. História e Património do Concelho de Albergaria-a-Velha. 6. Albergaria-a-Velha, pp. 23-34.

SILVA, António Manuel S. P.; LEMOS, Paulo A. P.; ALMEIDA E SILVA, Sara; SÁ, Edite (2020) - Estudo, Conservação e Valorização do sítio arqueológico de São Julião. Branca, Albergaria-a-Velha, Aveiro. Relatório da 6‥ campanha de trabalhos arqueológicos. Arouca: Centro de Arqueologia de Arouca. Texto policopiado

SOUTO, Alberto (1942) - Romanização no Baixo Vouga. Novo "oppidum" na zona de Talábriga. Trabalhos de Antropologia e Etnologia, 9(4). Porto, pp. 283-328.

VIEIRA, Alexandra (2014) - Alguns dados para o estudo da Idade do Bronze do Norte de Portugal. In A Idade do Bronze em Portugal: os dados e os problemas. Tomar: Instituto Politécnico de Tomar: 52-101.

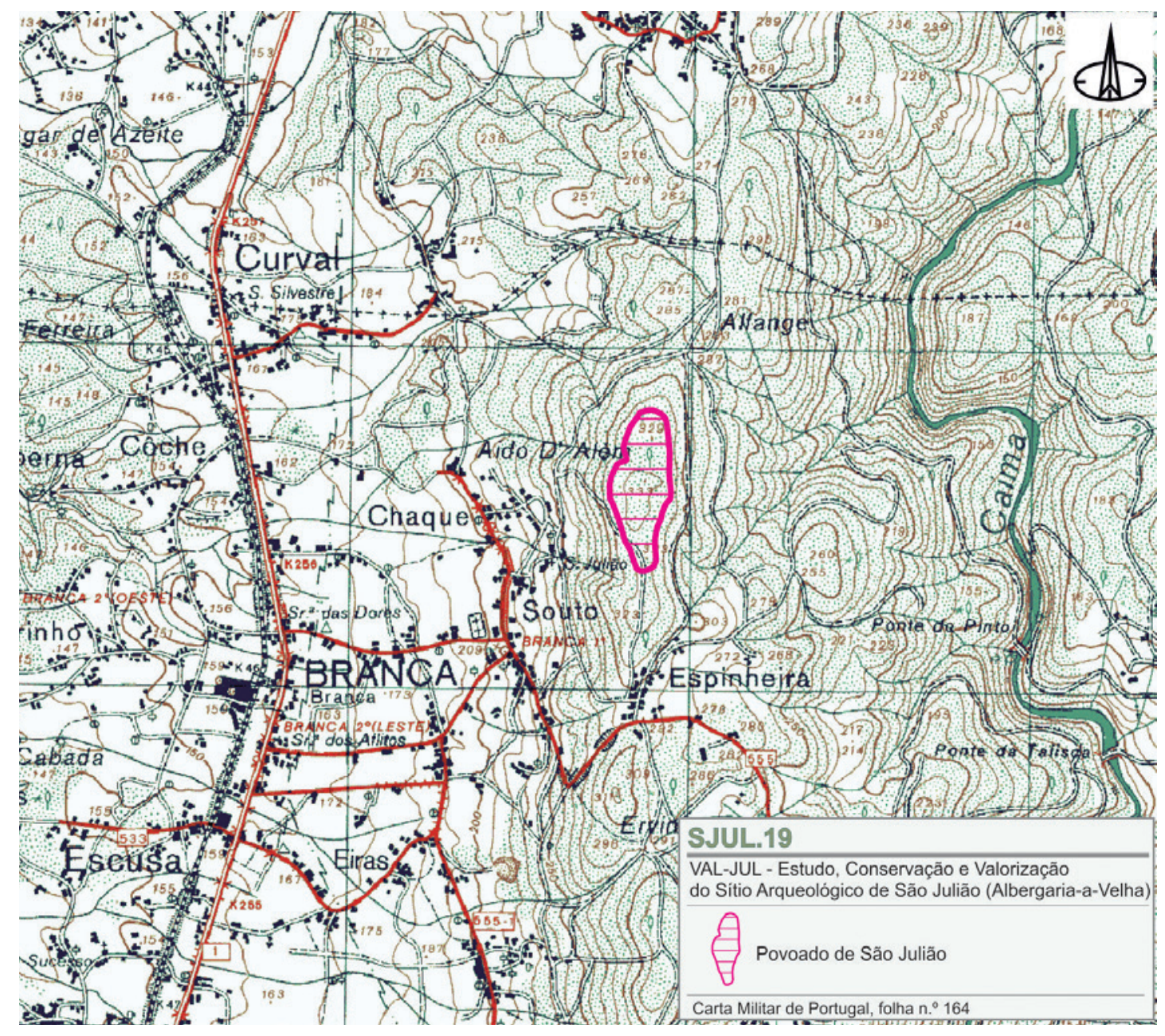

Figura 1 - Implantação do sítio arqueológico na Carta Militar de Portugal (Folha nํ164), à escala 1:2500o (reduzida), com demarcação da plataforma superior. 


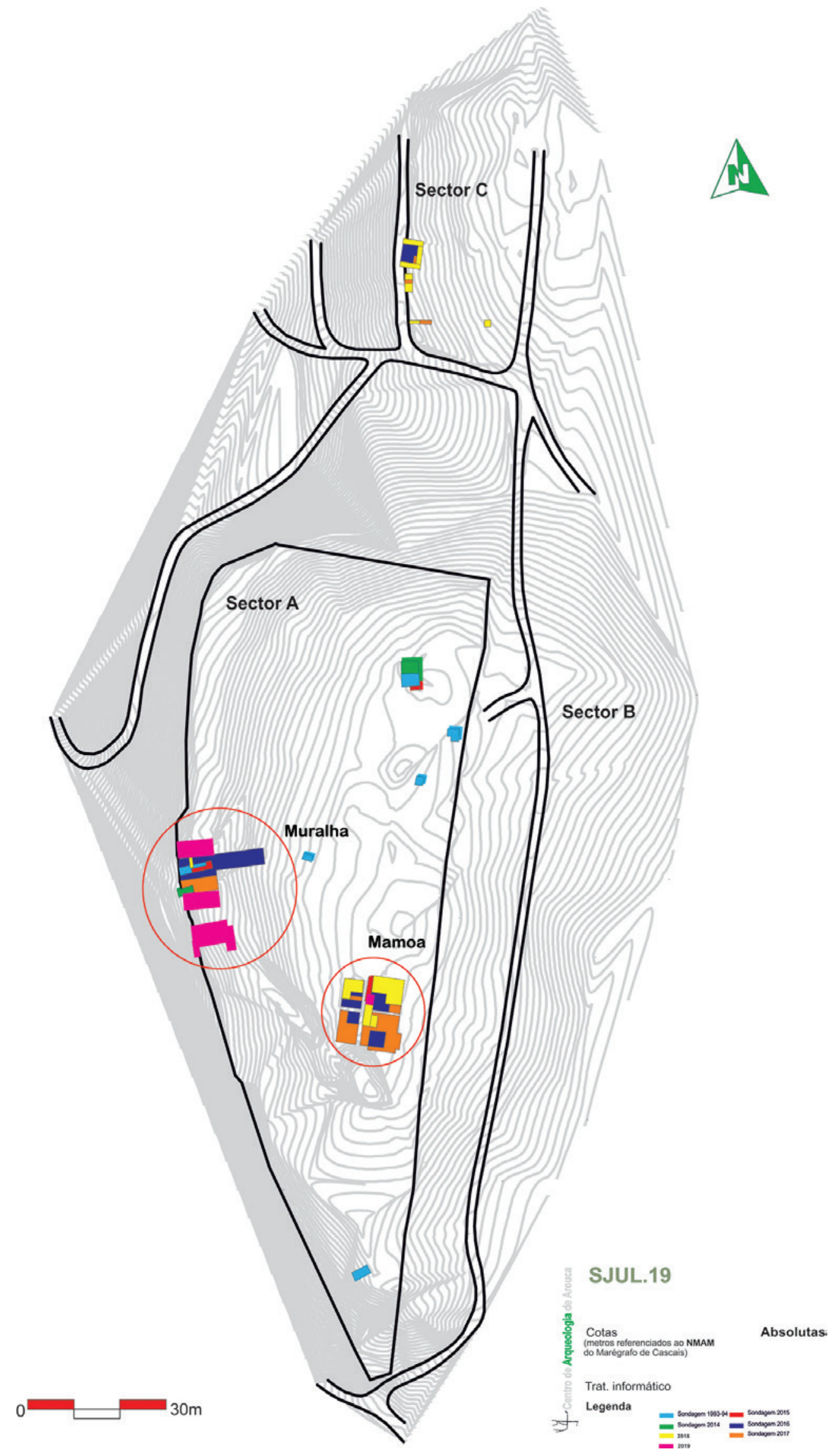

Figura 2 - Implantação das sondagens arqueológicas no sítio arqueológico (levantamento dos serviços de topografia da C. M. de Albergaria-a-Velha). 


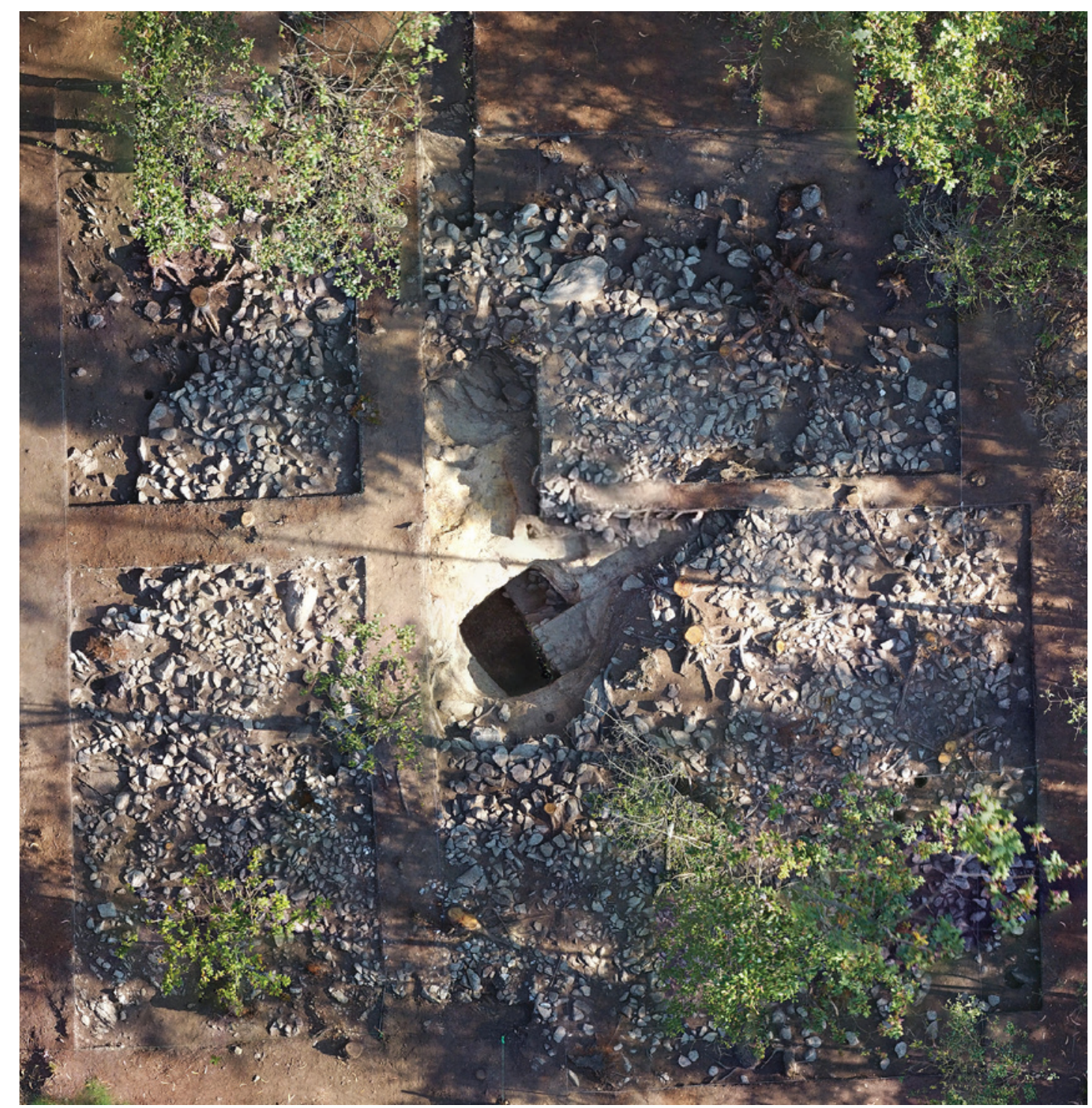

Figura 3 - Sector A. Mamoa de São Julião. Plano final 2019 (fotografia: Multimapa). 


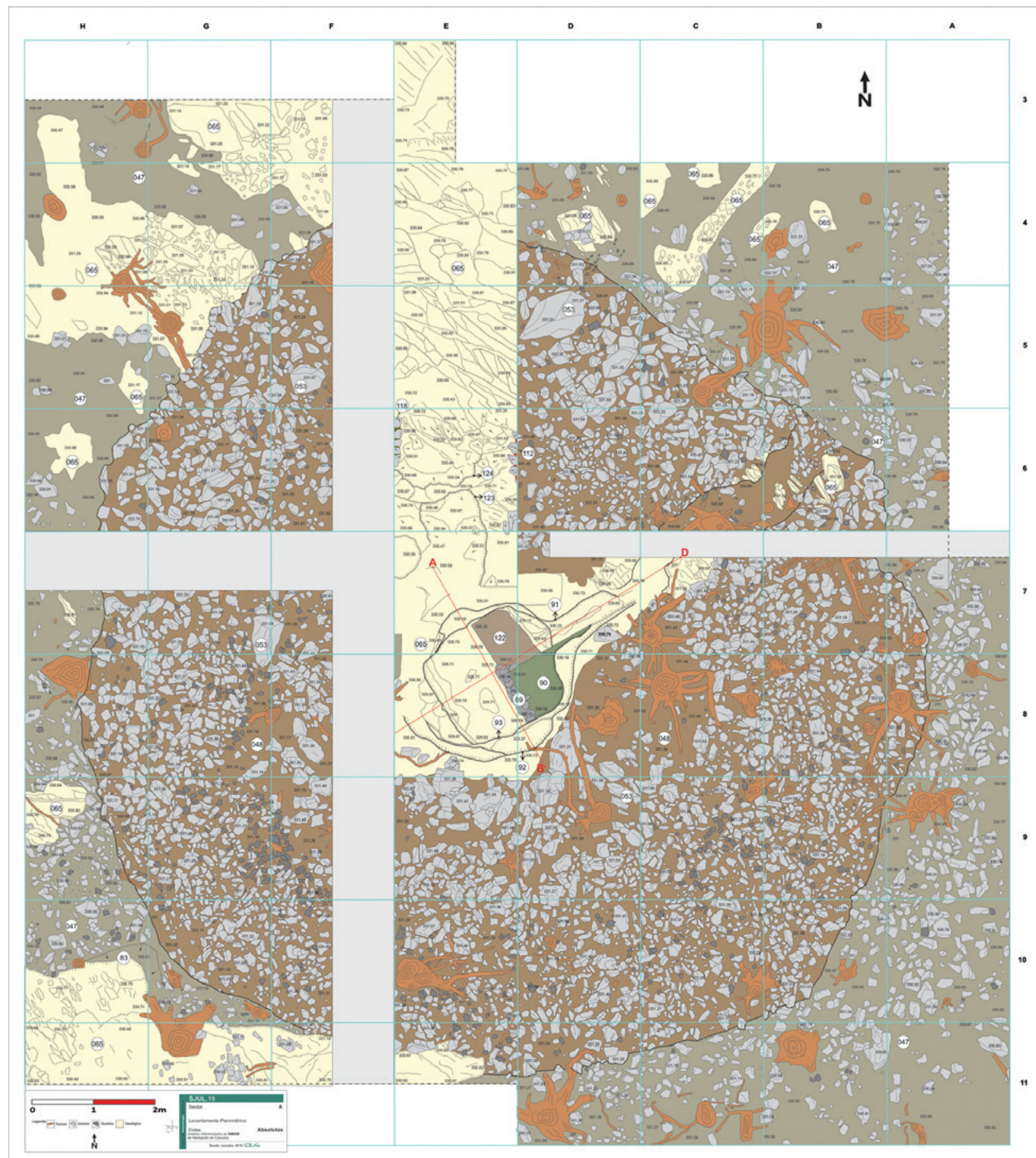

Figura 4 - Sector A. Mamoa de São Julião. Plano final 2019. 


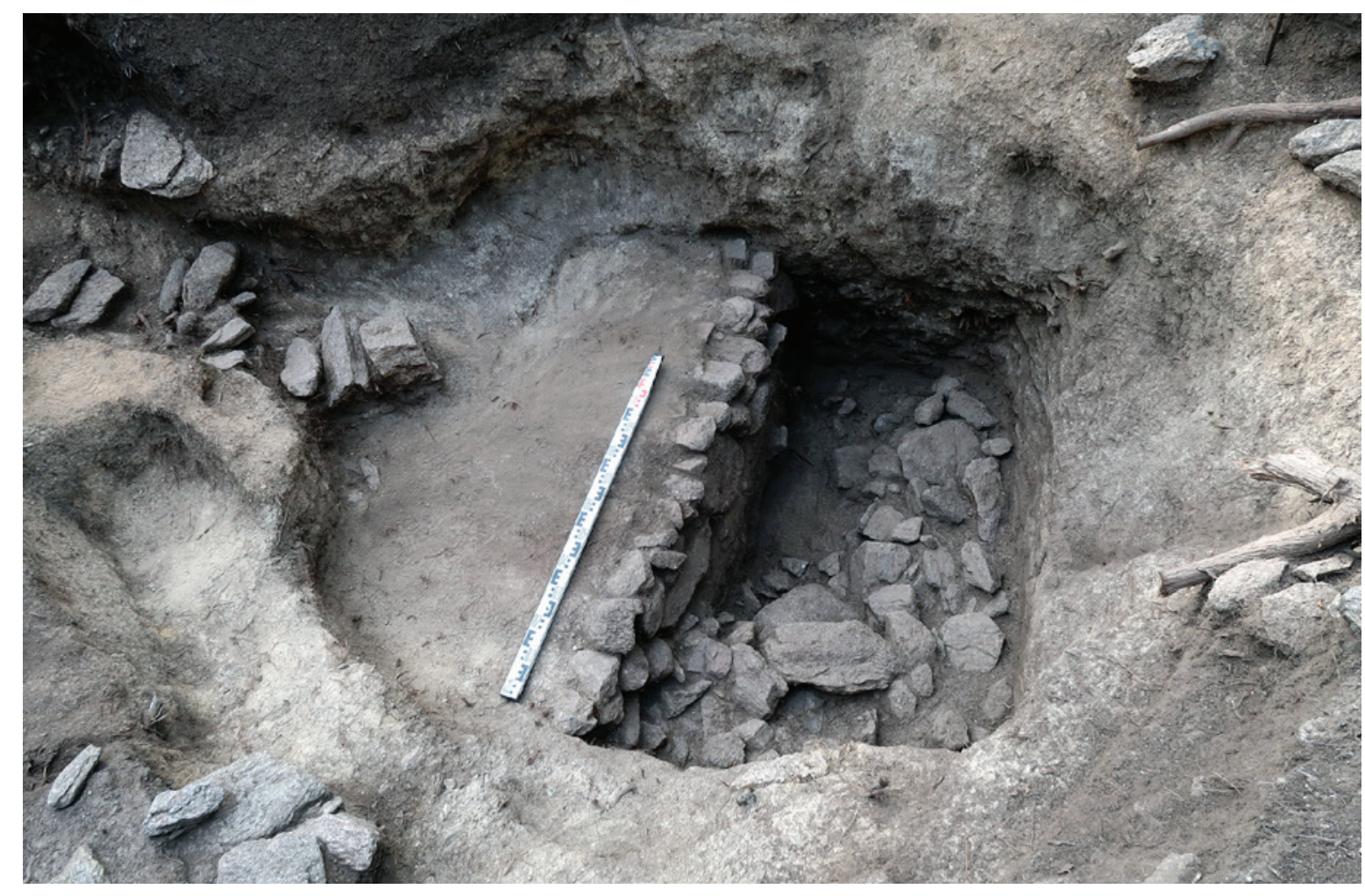

Figura 5-Sector A. Mamoa 1 de São Julião. Fossa central.

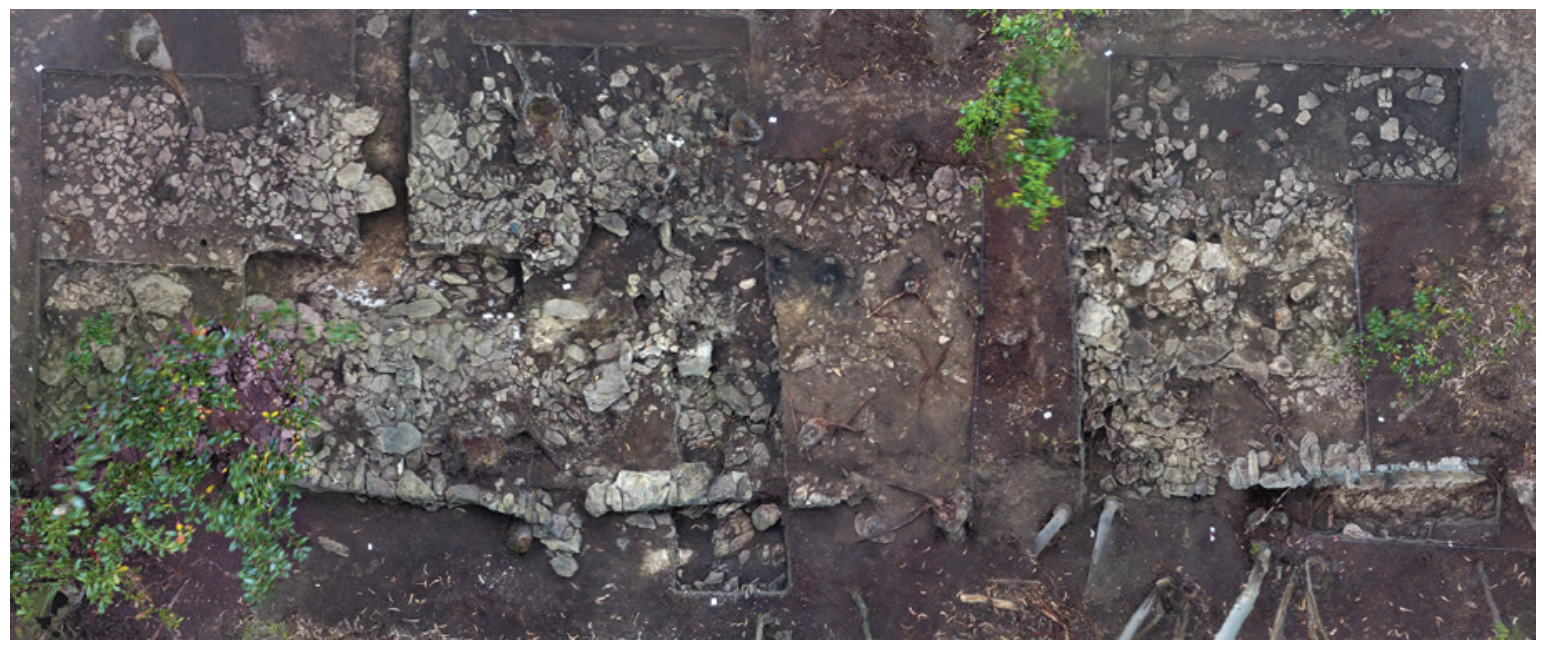

Figura 6 - Sector A. Estrutura de delimitação. Plano final 2019 (fotografia: Multimapa). 


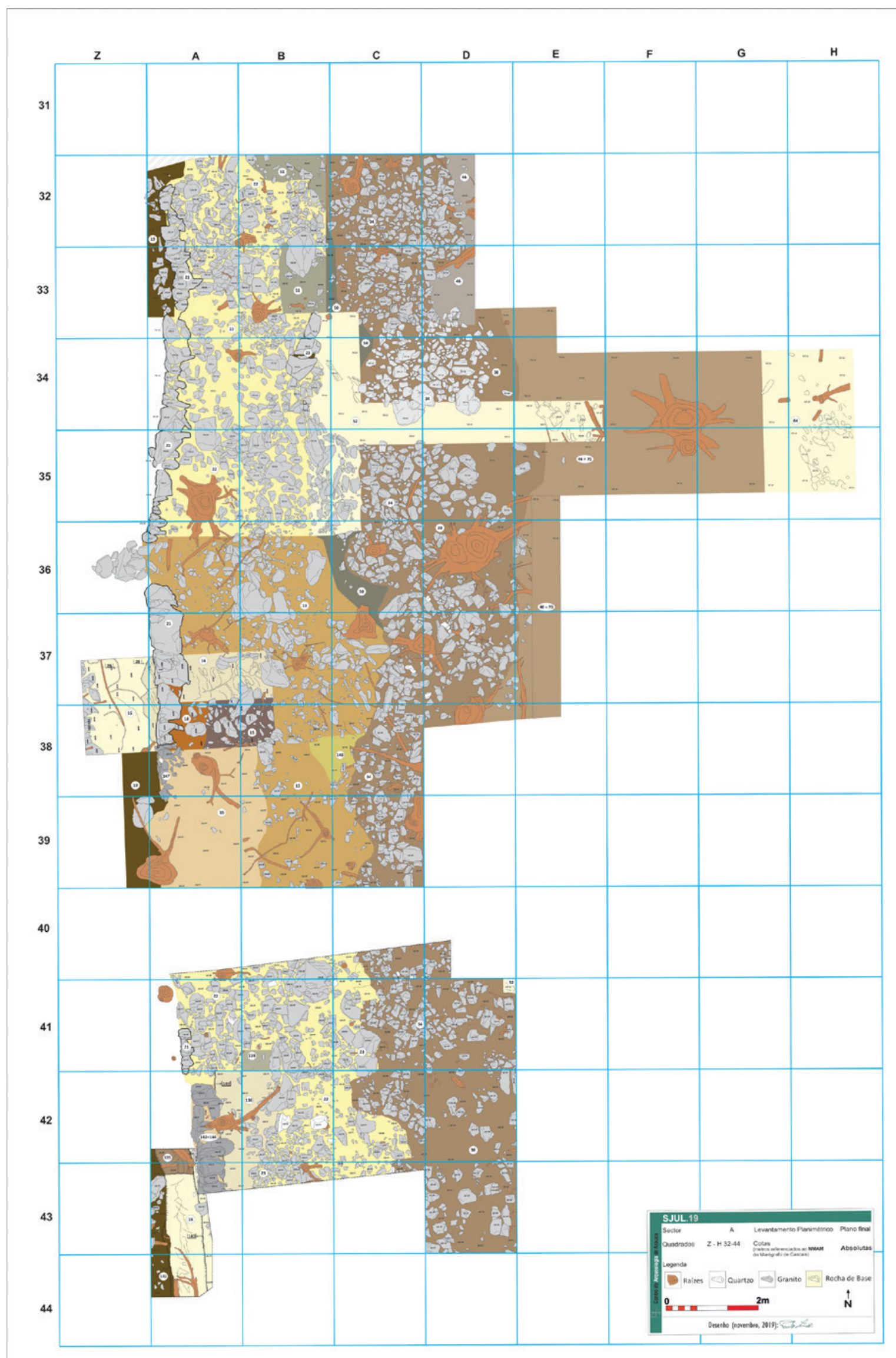

Figura 7 - Sector A. estrutura de delimitação. Plano final (2019). 

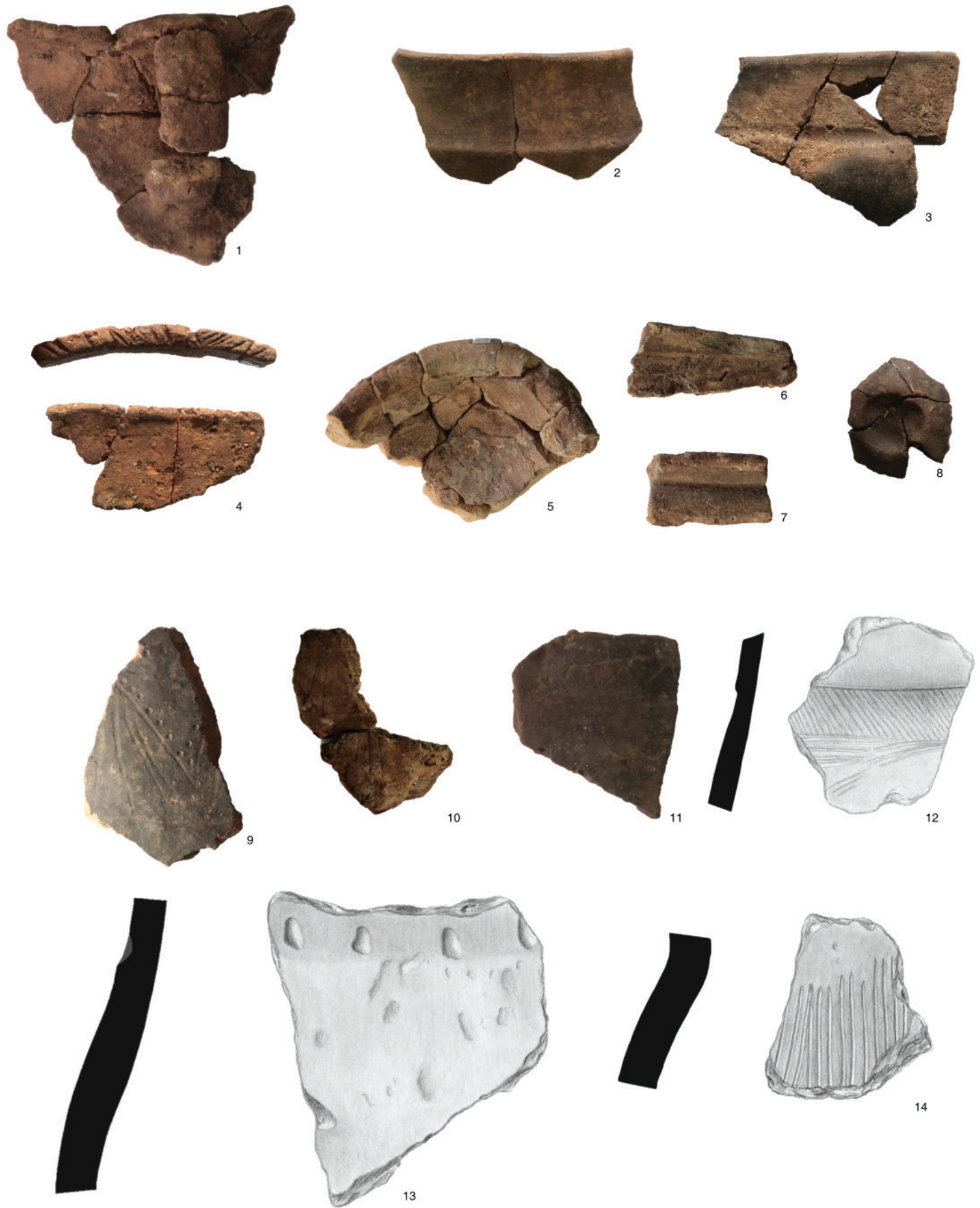

Figura 8 - Cerâmica de São Julião. (12 a 14 - desenhos: Amélia Marques/MDDS). 

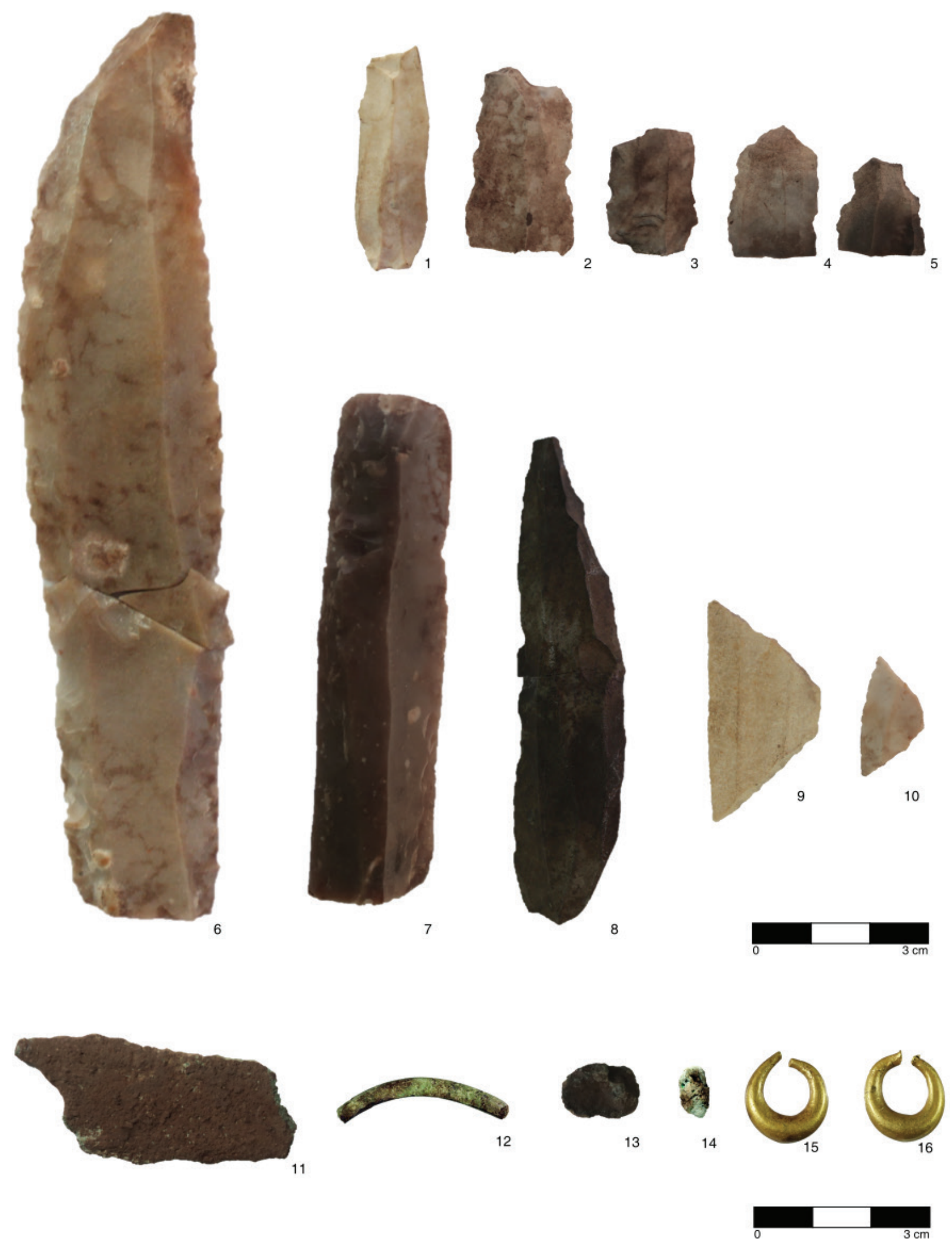

Figura 9 - Objetos líticos e metálicos de São Julião. (Fotos 12, 14, 15 e 16: M. Santos/MDDS). 


\begin{tabular}{|c|c|c|c|c|c|c|c|c|c|c|c|c|c|}
\hline \multirow{3}{*}{ № Lab } & \multirow{3}{*}{ Contexto } & \multirow{3}{*}{ Material } & \multirow{3}{*}{\begin{tabular}{|l|}
$\sigma(13 \mathrm{C})$ \\
per mil
\end{tabular}} & \multicolumn{2}{|c|}{$\begin{array}{c}\text { Fraction of } \\
\text { modern }\end{array}$} & \multirow{3}{*}{ BP } & \multirow{3}{*}{$\begin{array}{c}1 \\
\text { sigma }\end{array}$} & \multicolumn{2}{|c|}{ OxCAL $4.2[1]$} & \multicolumn{3}{|c|}{ Calib Rev 7.0.4 [2] } & \multirow{2}{*}{$\begin{array}{c}\text { CalPal_2007 } \\
\text { HULU [3] } \\
\text { Calendric Age } \\
\text { Cal BP }\end{array}$} \\
\hline & & & & \multirow{2}{*}{ pMC } & \multirow{2}{*}{$\begin{array}{l}1 \sigma \\
\text { error }\end{array}$} & & & 10 & $2 \sigma$ & $1 \sigma$ & $2 \sigma$ & \multirow{2}{*}{$\begin{array}{l}\text { Probab. } \\
\text { Mediana }\end{array}$} & \\
\hline & & & & & & & & $\begin{array}{c}68.2 \% \\
\text { probability }\end{array}$ & $\begin{array}{c}95.4 \% \\
\text { probability }\end{array}$ & $\begin{array}{c}68.3 \% \\
\text { probability }\end{array}$ & $\begin{array}{c}95.4 \% \\
\text { probability }\end{array}$ & & $68 \%$ \\
\hline \multirow{2}{*}{$\begin{array}{l}\text { D-AMS } \\
8883\end{array}$} & \multirow{2}{*}{$\begin{array}{c}\text { Sd } 2 \\
\text { UE } 026\end{array}$} & \multirow{2}{*}{$\begin{array}{c}\text { Carvão } \\
\text { arbutus } \\
\text { unedo }\end{array}$} & \multirow{2}{*}{-21.3} & \multirow{2}{*}{70.98} & \multirow{2}{*}{0.26} & \multirow{2}{*}{2753} & \multirow{2}{*}{29} & \multirow{2}{*}{$\begin{array}{c}920 \mathrm{BC} \\
(68.2 \%) \\
843 \mathrm{BC}\end{array}$} & \multirow{2}{*}{$\begin{array}{l}976 \mathrm{BC} \\
(95.4 \%) \\
826 \mathrm{BC}\end{array}$} & $\begin{array}{c}920 \mathrm{BC} \\
(46.3 \%) \\
887 \mathrm{BC}\end{array}$ & $\begin{array}{c}975 \mathrm{BC} \\
(07.1 \%) \\
951 \mathrm{BC}\end{array}$ & \multirow{2}{*}{-891} & \multirow{2}{*}{$893 \pm 35$} \\
\hline & & & & & & & & & & $\begin{array}{c}884 \mathrm{BC} \\
(53.7 \%) \\
844 \mathrm{BC}\end{array}$ & $\begin{array}{l}945 \mathrm{BC} \\
(92.9 \%) \\
827 \mathrm{BC}\end{array}$ & & \\
\hline \multirow{2}{*}{$\begin{array}{l}\text { D-AMS } \\
033464\end{array}$} & \multirow{2}{*}{$\begin{array}{l}\text { Sect. C } \\
\text { UE } 075\end{array}$} & \multirow{2}{*}{$\begin{array}{c}\text { Sementes } \\
\text { Triticum } \\
\text { sp. }\end{array}$} & \multirow{2}{*}{ n.i. } & \multirow{2}{*}{70.76} & \multirow{2}{*}{0.27} & \multirow{2}{*}{2778} & \multirow{2}{*}{31} & $\begin{array}{c}978 B C \\
(64.6 \%) \\
894 B C\end{array}$ & \multirow{2}{*}{$\begin{array}{c}1002 B C \\
(95.4 \%) \\
842 B C\end{array}$} & $\begin{array}{c}977 \mathrm{BC} \\
(95.1 \%) \\
895 \mathrm{BC}\end{array}$ & \multirow{2}{*}{$\begin{array}{c}1002 B C \\
(100 \%) \\
843 B C\end{array}$} & \multirow{2}{*}{-925} & \multirow{2}{*}{$930 \pm 44$} \\
\hline & & & & & & & & $\begin{array}{l}864 B C \\
(3.6 \%) \\
857 B C\end{array}$ & & $\begin{array}{l}864 \mathrm{BC} \\
(4.9 \%) \\
857 \mathrm{BC}\end{array}$ & & & \\
\hline
\end{tabular}

[1] OxCal v4.2.4 Bronk Ramsey (2013); r:5; IntCal13 atmospheric curve (Reimer et al 2013); OxCal v4.2.4 Bronk Ramsey (2013); r:5

[2] RADIOCARBON CALIBRATION PROGRAM*. CALIB REV7.1.0. Copyright 1986-2018 M Stuiver and PJ Reimer, *To be used in conjunction with: Stuiver, M., and Reimer, P.J., 1993,

Radiocarbon, 35, 215-230. Reimer PJ, Bard E, Bayliss A, Beck JW, Blackwell PG, Bronk Ramsey C, Buck CE, Cheng H, Edwards RL, Friedrich M, Grootes PM, Guilderson TP, Haflidason H, Hajdas

I, Hatté C, Heaton TJ, Hogg AG, Hughen KA, Kaiser KF, Kromer B, Manning SW, Niu M, Reimer RW, Richards DA, Scott EM, Southon JR, Turney CSM, van der Plicht J.

[3] quickcal2007 ver.1.5. Monrepos. Archäologisches Forschungszentrum und Museum für menschliche Verhaltensevolution. http://www.calpal-online.de

n.i. - não indicado

Quadro 1 - Datações absolutas, calibradas, do povoado de São Julião da Branca. 


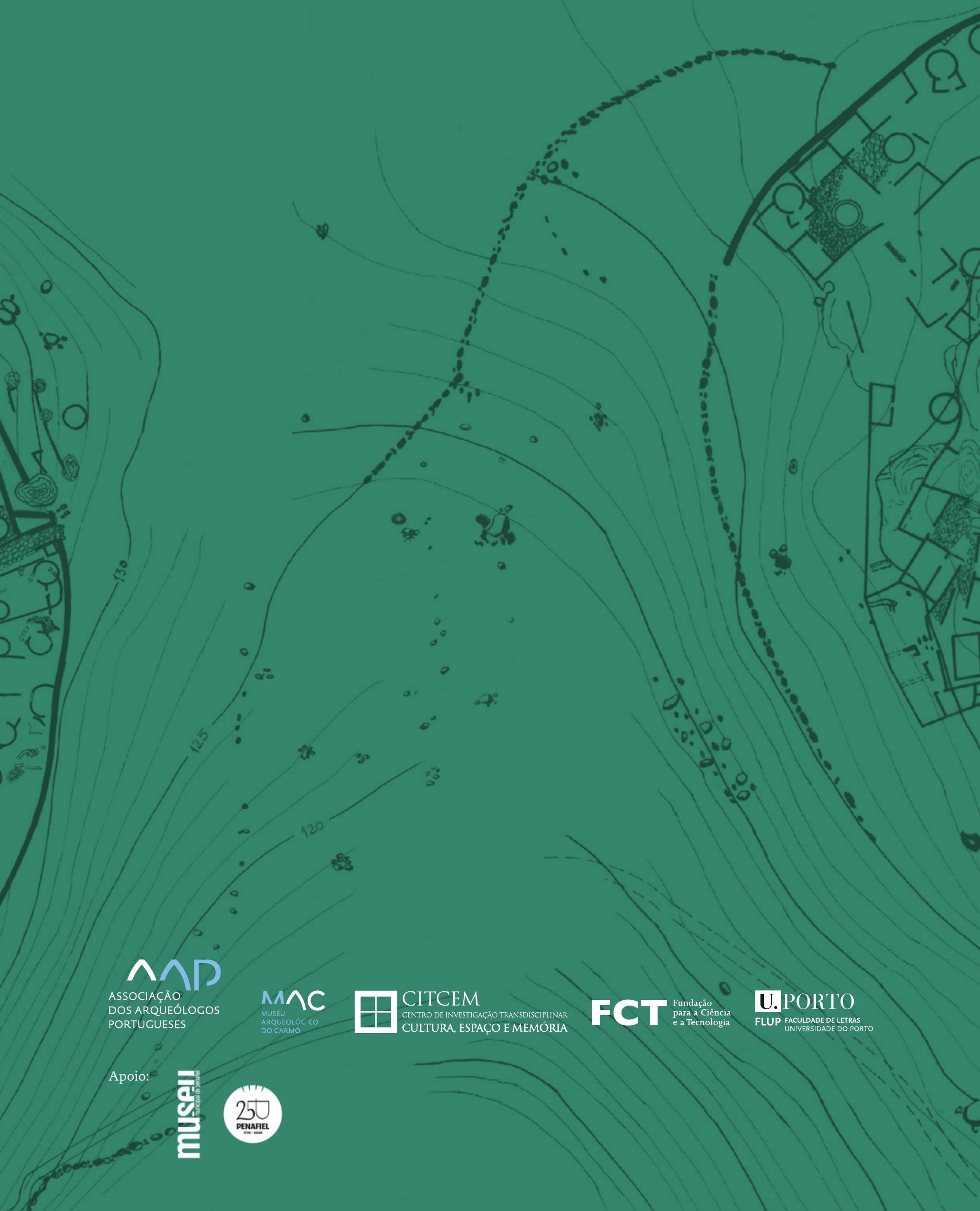

